\title{
Hinterlands, Urban Centers, and Mobile Settings: The "New" Old World Archaeology from the Eurasian Steppe
}

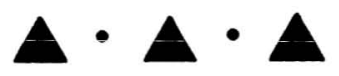

\author{
WILLIAM HONEYCHURCH AND CHUNAG AMARTUVSHIN
}

"Without PASTURE THERE ARE NO HERDS, without herds there is no food, and without food there are no people" is a Mongolian proverb, the significance of which the two of us came to understand during the spring of 1993 by way of acquaintance with the herder, Tumen, of Bayankhongor Province. ${ }^{1}$ As is common at this time of year, Tumen's sheep and goats were emerging famished from a harsh steppe winter and were dependent on the first spring grasses to replenish their strength. In the next few days, unseasonable and unpredictable snowstorms, called zud, began to blow across the southwestern provinces of Mongolia, icing and destroying the delicate new pasture. Tumen's weakest animals began dying after a day and a half without access to grazing, and by the end of the week most local herders had lost significant portions of their herds and their livelihood. This was only the first of several spring zud episodes that were to sweep through Mongolia during the 1990s and that would eventually lead to large-scale international assistance to the country in 1999 and 2000.

Mongol folk sayings tend to reflect the experience of a highly specialized pastoral way of life that is still common on the Mongolian steppe today. Anatoly Khazanov (1994) has argued that groups inhabiting marginal environments and devoting a majority of subsistence effort to mobile and extensive herding are often unable to maintain a balance between available pasture, herd numbers, and human population due to unpredictable variability in the environment. $Z u d$, epizootic diseases, steppe fires, and drought require that a system of pastoral specialization be supplemented and buffered against productive risk, and though evidence suggests that extended families might survive on herd animals alone, diversification strategies are a more plausible - and probably necessary-form of subsistence management. Archaeological studies from Mongolia and Siberia have hypothesized that early steppe economies were most likely based on multiresource nomadism (Salzman 1972:67) during the second and first millennium B.C., including various forms of livestock herding, agricultural production, hunt-

William Honeychurch is a research associate in the Department of Anthropology of the Smithsonian Institution in Washington DC. Chunag Amartuvshin is a senior research archaeologist at the Institute of Archaeology in the Academy of Sciences, Ulaanbaatar, Mongolia.

Asian Perspectives, Vol. 46, No. 1 (C) 2007 by the University of Hawai'i Press. 
ing, fishing, and gathering of wild fruits and vegetables (Grishin 1981: 196). These same intermixed subsistence activities have been documented ethnographically for the Siberia-Mongolia region (Erdenebaatar 2000; Vainshtein 1980).

Buffering against productive risk can take many forms according to the range of resource types, storage technologies, spatial and temporal dispersion, techniques for "social storage," and the hierarchy of scale at which supportive social networks operate (Halstead and O'Shea 1989). A further risk buffering characteristic of multiresource nomadism is the systemic flexibility to readily adjust resource emphasis and degree of mobility and intensification relative to the physical, biological, and social environment (LaBianca 1990:12). As Cribb (1991:16, 25) has observed, such a sliding-scale approach to diversified subsistence production also includes changes in social scale at which subsistence production occurs. For example, an increase in pastoral production, at the level of the extended family, may occur at the expense of local agricultural and hunting-gathering activities due to participation in broader networks through which these other products can be reliably obtained. If, however, such networks collapse, the family in question may opt to return to a more diversified production strategy at the level of the extended family unit. The potential for shifting investment in a range of resources and regimes of mobility at different levels of social integration is a primary feature of the Inner Asian ${ }^{2}$ adaptation to an unpredictable environment that is more accurately described as unpredictable as opposed to "marginal." Consequently, this makes for a complex economic and political foundation for the kinds of regional polities that appeared across the territories of Inner Mongolia, Mongolia, and southern Siberia as early as 200 B.C.- most notably those of the Xiongnu, Turk, Uighur, and imperial Mongols (Lattimore 1992 [1940]).

Khazanov (1994:166-169, 228-302) has listed common structural characteristics of complex nomadic polities including hereditary social stratification, multitiered administrative hierarchy, regional levels of integration, military and trade specializations, and in some cases, urbanization. On the other hand, he emphasizes the flexible or loose structures of nomadic polities such as "dispositional" leadership, cyclical centralization, factional and shifting allegiance, and the potential for rapid political integration or deintegration. In the case of Inner Asian nomadic confederations, a good deal of historical research has been devoted to the question of how and why dispersed nomadic groups developed regional polities capable of competing with mature sedentary states (Jagchid and Symons 1989; Lattimore 1992 [1940]; Yamada 1982). Anthropological theory on nomadic complexity has emphasized the dependent relationship between peripheral nomadic groups and neighboring agricultural state societies with which they often interacted (Burnham 1979; Irons 1979; Khazanov 1994). The most recent anthropological research on Inner Asian polities, likewise, predicates the development of regional complex organization on interaction with the dynasties of neighboring China (Barfield 2001). The data used for these studies come primarily from the Chinese historical annals in which biased and often pejorative accounts of steppe peoples are recorded. The problems of relying on such external reports for the reconstruction of early steppe society have been a long-standing source of frustration for scholars of Inner Asia (Sinor 1970:108-109).

While the work of researchers such as Thomas Barfield $(1981,1989,2001)$ and Nikolai Kradin $(2000,2002)$ on nomadic polities is well documented and com- 
pelling, there is potential for the refinement of these models based on a more detailed analysis of the local conditions within steppe regions, including the role of multiresource productive systems. Barfield's model for Inner Asian polities emphasizes political and military appropriation of resources from China as the primary source of organizational support. In terms of indigenous systems of economic finance, Barfield, as well as a number of Inner Asian historians, view steppe agro-pastoral production as relatively undifferentiated, confined to the local level, and disarticulated from the organization of regional political structure (Barfield 1989:7-8; Fletcher 1986:14-15; Sinor 1970:98). In recent critiques, however, both historians and archaeologists have argued that "evidence suggest" the presence of complex and differentiated agro-pastoral economies having both extensive and intensive sectors during periods of regional steppe organization (Chang and Tourtellotte 1998:267; DiCosmo 1994; Rogers et al. 2005). In order to explore this topic further and add what we believe is a unique perspective from northern Mongolia, archaeological site data from a recent survey of the Egiin Gol Valley have been analyzed to discover whether changes in agropastoral subsistence production can be detected during periods of regional organization. Our objective in this paper is twofold: first, to evaluate the hypothesis that agro-pastoral production is disarticulated from changes in steppe political organization, and second, to discover how changes in local subsistence production, if present, might provide further insight into the structure of the finance and political integration of nomadic polities. Our results suggest that the flexibility and diversity of multiresource nomadism may have played a greater role in the structuring of nomadic polities than might be expected. We then assess the recent advent of Eurasian anthropological archaeology and its promise for research on nomadic pastoralism in particular and for comparative perspectives in anthropology generally.

THE STUDY AREA: AGRICULTURE, PASTORALISM, AND ENVIRONMENT

The Egiin Gol River $\left(49^{\circ} 27^{\prime} \mathrm{N}, 103^{\circ} 28^{\prime} \mathrm{E}\right.$; Figs. 1 and 2$)$ is a major tributary of the Selenge River system, which feeds into Lake Baikal, Siberia. Near its confluence with the Selenge, the lower Egiin Gol River flows in an easterly to southeasterly direction and meanders along a floodplain varying in width from 0.8 to $1.5 \mathrm{~km}$. Elevations within the survey area range between 840 and $1250 \mathrm{~m}$ above sea level and the landscape is characterized by northeast-trending ridges that alternate with narrow, v-shaped and flat-floored valleys formed by tributaries of the Egiin Gol River. Land cover consists of steppe grasses, shrubs, and medium-dense forest cover of birch, pine, and larch on the north-facing slopes of the ridge system. Mean annual precipitation in the area is $340 \mathrm{~mm}$ and soil quality is sufficient to support extensive dry-farmed agriculture at the present time. Canal-irrigated agriculture was practiced in the area during the nineteenth and early twentieth centuries. Systematic, pedestrian survey was carried out over a five-year period (19962000 ) and encompassed a $310 \mathrm{~km}^{2}$ area consisting of the main Egiin Gol valley, tributary valleys, and low-lying and upper ridges. In excess of 550 archaeological sites have been recorded, dating from the Early Upper Paleolithic to the midtwentieth century, including cemeteries, settlements, ritual stelae and petroglyphs, 


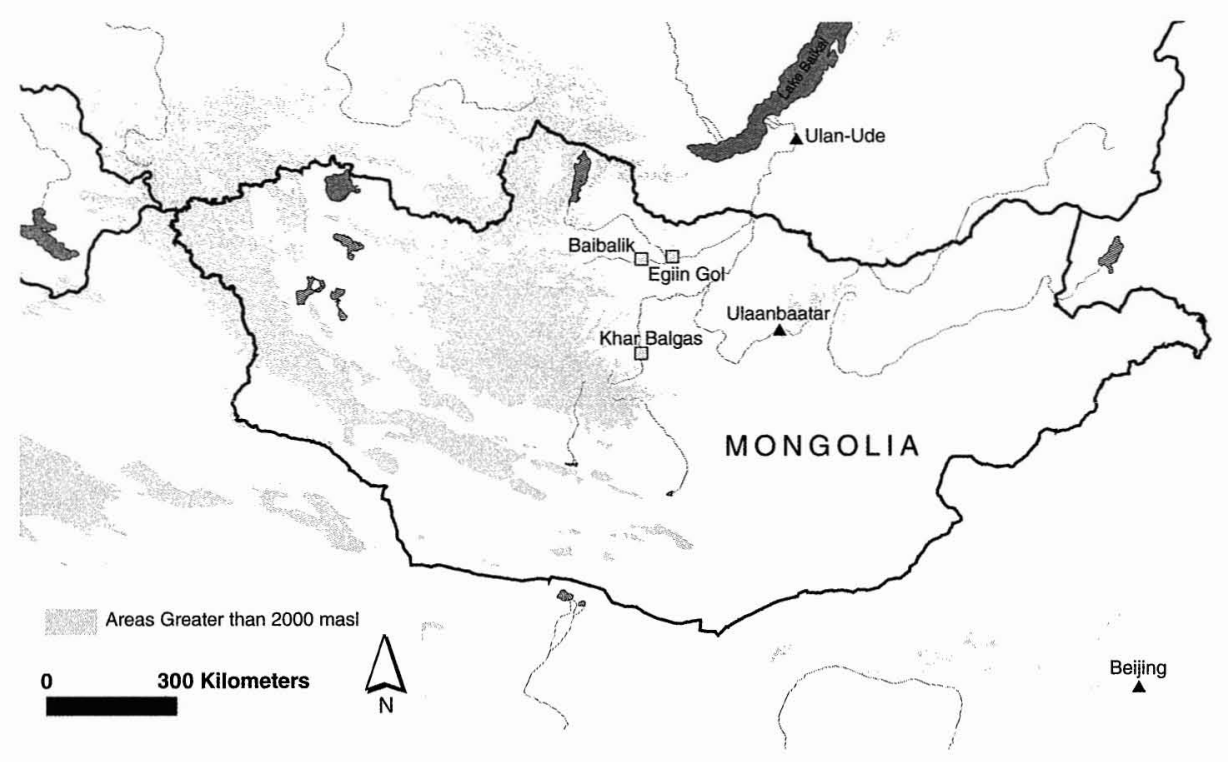

Fig. 1. The eastern Eurasian steppe and sites mentioned in text.

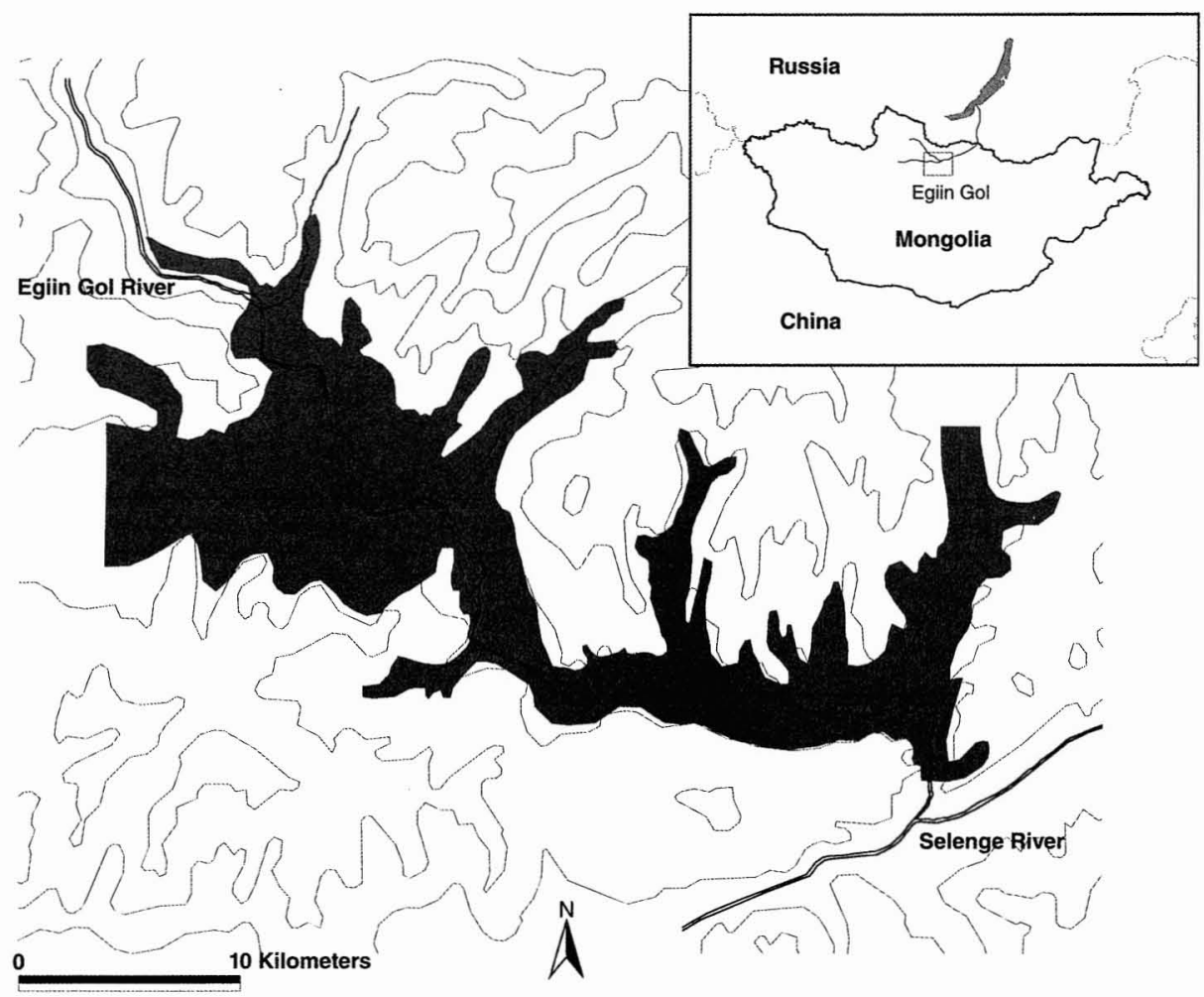

Fig. 2. The lower Egiin Gol region of northern Mongolia. Areas in gray represent the 1996-2000 survey area. Contours represent intervals of approximately $300 \mathrm{~m}$. Survey transects across higher elevation areas are not depicted. 
as well as areas having evidence for metal production and the use of domesticated grain. Over 100 artifact scatters have been recovered that have been interpreted as seasonal campsites and dated in many cases to the periods of major nomadic confederations on the territory of Mongolia. Sites contemporary with the Xiongnu (c. 209 B.C.-A.D. 93) and Orkhon Uighur (A.D. 744-840) polities will be used to study changes in local subsistence production in the Egiin Gol Valley through an analysis of site location and productive resource zones.

The Egiin Gol Valley has a recent history of both pastoral and agricultural production, and these patterns have been studied as examples of ways in which the valley landscape might be organized with reference to these productive systems. Currently, over 20 herding families inhabit the valley, making relatively shortdistance seasonal movements in order to maintain herds of sheep, goats, cattle, and horses. The forest-steppe zone of northern and central Mongolia in which the study area is located is considered to be a relatively "rich" area in comparison to other parts of the country due to high annual precipitation and low interannual variability (Humphrey and Sneath $1999: 272$ ). Seasonal mobility in the valley is currently based on a three- to four-season system, with some families opting to maintain their summer site well into autumn, while others establish new campsites at the family's discretion. Seasonal camp size varies from between one and two families in winter to three to four khot ail family groups in summer. Campsites in the valley that are most distinctive spatially are those of summer and winter, while spring campsites usually fall in an intermediate area between these two (Fig. 3). ${ }^{3}$

Winter camps tend to be located in the middle to upper reaches of tributary valleys extending away from the main Egiin Gol basin, while summer camps are mostly along the Egiin Gol River. Herders describe a good winter site as a location protected from the wind, having access to grasses close to the snow surface, and having proximity to early, snow-free spring pastures. These concerns reflect an important point for pastoral production and one also emphasized by Khazanov (1994:70) and other researchers: Herd size - and consequently the number of herders in the valley-will be determined by the carrying capacity of the least productive pasture. In the case of the Egiin Gol Valley, the availability and productivity of pastures from late winter through spring and into early summer represent the critical resource period. It is during this time that locally harvested fodder supplies run low and animals must rely upon available vegetation and stored body fat for their own maintenance and nurturing their young. Snowmelt in late March is important for encouraging pasture growth, but it is not until the rains come in middle June that pasture becomes abundant and generalized within the valley to the extent that the choice of camp locations is governed by secondary concerns. By late June and early July, the Egiin Gol herds are fully stabilized and animals are progressing toward their maximal body weight, which will be maintained through autumn and early winter (Erdenebaatar 2000). The total extent of campsite movement at Egiin Gol is usually not more than $8-15 \mathrm{~km}$ in range. These short-distance seasonal movements from the upper valley reaches to the lower valleys correspond to the Khangai pattern of mobility described by Simukov (1934) in the early twentieth century. Recent influences that may have affected the pattern of pastoral production at Egiin Gol include the construction of large wooden shelters for winter campsites sponsored by the central govern- 


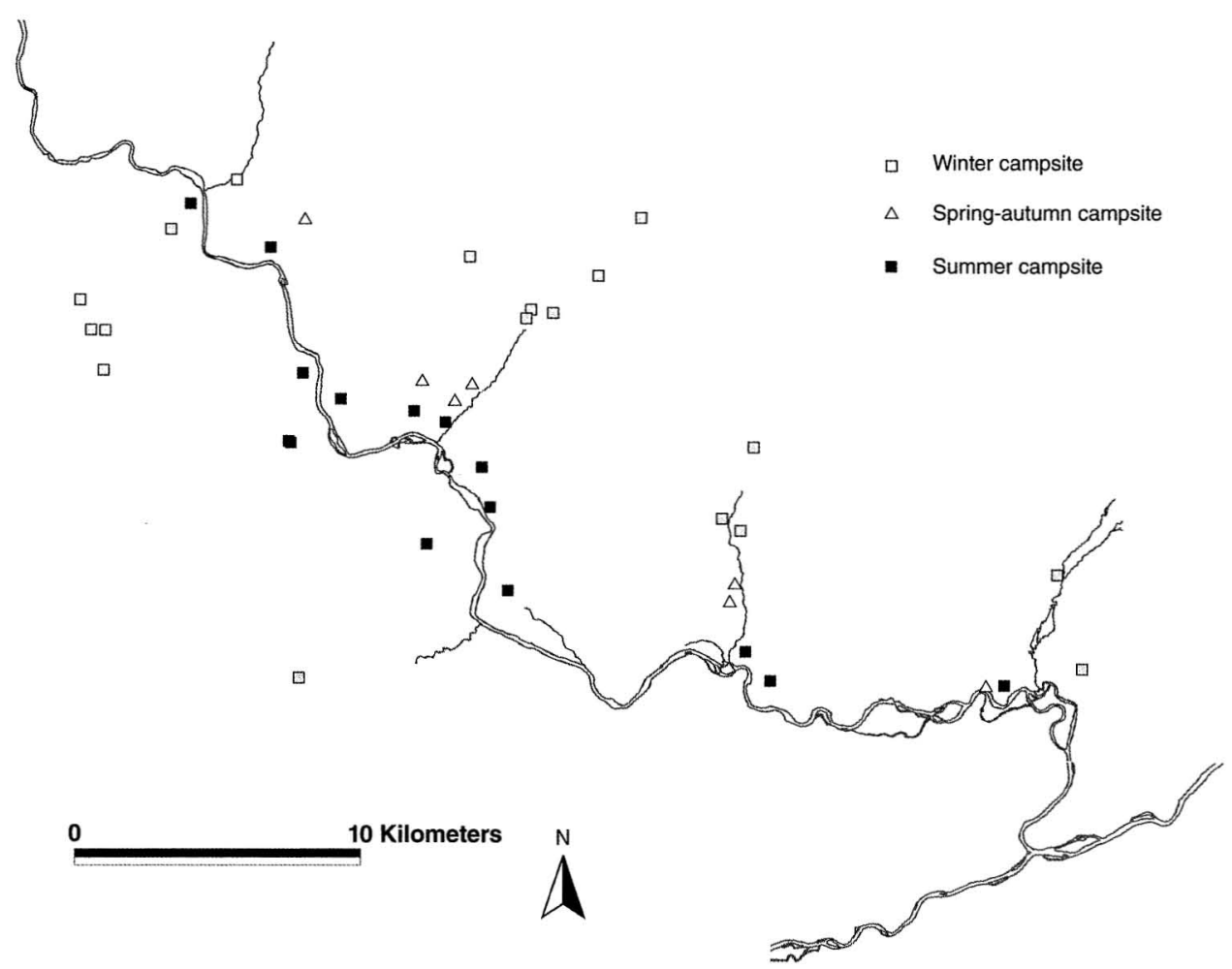

Fig. 3. Map of contemporary Egiin Gol herding camps by season (Erdenebaatar 2000).

ment, administrative districting that may have limited the potential range of movement, and population outflow from the valley by younger individuals seeking employment in urban areas.

Agricultural production at Egiin Gol has taken various forms over the past 200-300 years, varying in scope and intensity. Farming in the valley has included runoff irrigation and dry-farming practices in place under the Lamaist monastery system in the eighteenth and nineteenth centuries, large-area mechanized agriculture carried out today, and the small dry-farmed garden plots maintained by herding families near their summer campsites. The growing season is short in duration, running from May to September, and the rich colluvial soils in the middle to lower reaches of tributary valleys are considered to be the most productive. The current agricultural practices carried out by large cooperatives involve the use of tractor and combine crews, genetically modified wheat seed, and rainfall-based watering. Fields for wheat and fodder crops are ploughed and seeded in the late spring, left unattended through the summer, and harvested in autumn. The digitized outline of modern fields in Figure 4 (drawn from maps at 1:25,000 scale) shows both the extensive size of these fields and the fact that they occupy the areas in the valley easily accessible by tractor crews through the main incoming and outgoing mountain passes. Relict fields from agricultural production carried out by valley inhabitants under the direction of local Buddhist monasteries can 


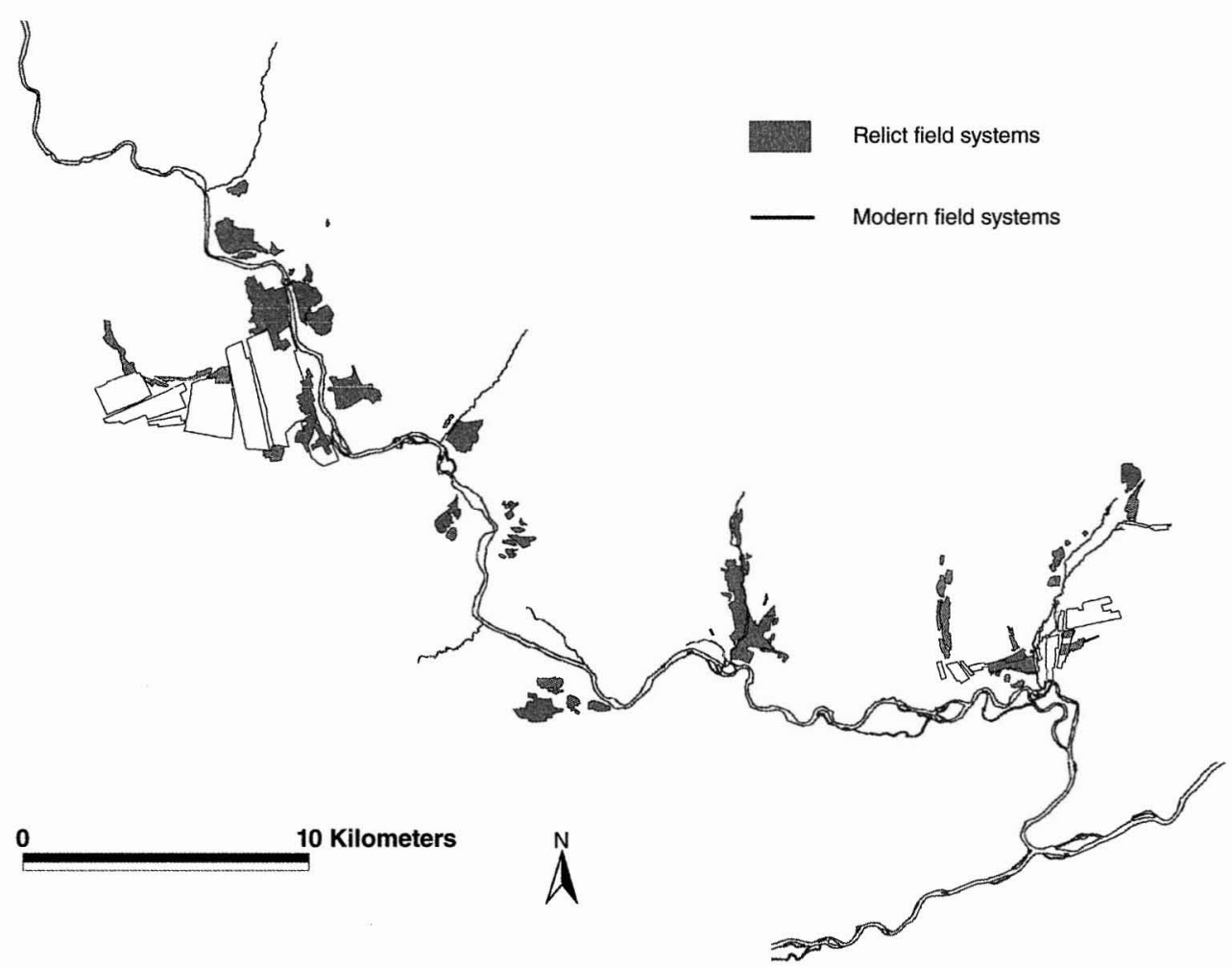

Fig. 4. Agricultural field distribution in Egiin Gol Valley.

still be clearly seen on aerial photos. Buddhist activity in the region surrounding Egiin Gol dates from the eighteenth century; however, the earliest construction date obtained for a monastery within the survey area is from the nineteenth century. Relict field systems have been digitized from 1:25,000 scale aerial photos obtained from the Mongolian government and show a locational preference for both tributary and main valley colluvial soils in the vicinity of either seasonal or permanent water sources (Fig. 4). ${ }^{4}$ Shallow irrigation ditches are associated with the relict fields, though in most cases these waterways do not lead back to riverine takeoff points but instead are designed to circulate snowmelt and rainfall across the upper edges of the fields. We associate this agricultural activity with the Buddhist monasteries in the valley based upon local informant accounts, historical records, and the presence of granite millstones and other agricultural implements discovered at monastery sites and in the vicinity of relict fields.

We should mention briefly that families currently inhabiting the Egiin Gol Valley do invest in summer hunting and gathering (Erdenebaatar 2000). This is less a necessary subsistence need than a traditional pattern that families clearly enjoy perpetuating. These activities do, however, support the idea that a tripartite subsistence economy is plausible for the valley. Animals currently hunted include deer, elk, wild boar, and wolves for their pelts. Given the amount of large rodent activity observed at archaeological sites in Egiin Gol, steppe marmots probably 
inhabited the valley not long ago and may have been hunted to the point of local extinction, since their meat is considered a delicacy among Mongols. Families also collect a wide range of seasonal fruits, berries, and vegetables, which are used as seasonings in cooking and in teas, made into jams, and also eaten directly off the bush. Fish are plentiful in the Egiin Gol and some tributary rivers; however, a long-standing Buddhist prohibition against disturbing fish has reduced the number of local residents willing to catch and eat them.

In terms of developing a model for Egiin Gol pastoral and agricultural landscape organization in the past, the ethnographic and ethnohistorical patterns described above are a plausible beginning. The pastoral patterning of upper and lower valley sites has been documented for a period of approximately 100 years before present and is highly functional given the topographical arrangement of the valley and the seasonal needs of both people and herd animals. The nineteenthcentury relict field extents provide more information about land surfaces well suited for agricultural production than would a simple soil zone typology. These fields are located in areas where ground surface runoff, slope, and solar exposure characteristics, as well as superior soils, combine to produce what are likely the plots of high use value. ${ }^{5}$ Furthermore, the nineteenth-century relict fields were worked with simple traditional technologies and represent those areas that can be exploited efficiently by techniques that are not dramatically different from those of earlier periods. One obvious problem with using models developed from observations over the past 200 years is the issue of palaeoclimate. To date, no palaeoclimatic studies have been conducted in the vicinity of the survey area, and the nearest region with high-quality data is that of Lake Baikal, Siberia, at a distance of approximately $300 \mathrm{~km}$ north of Egiin Gol. Recent pedological and lakecore microfossil research at Lake Baikal has detailed changes in Holocene temperatures and humidity suggesting that the periods of the Xiongnu and Uighur polities were cooler and less humid than at any time during the past 200-300 years (Karabanov et al. 2000:220). Such differences in climate would have altered both pastoral and agricultural conditions at Egiin Gol, but to what degree is not known. For the present study, we use the ethnographic and ethnohistorical models described above as proxies for productive conditions in the Egiin Gol Valley, and we assume that changes in local climatic conditions affected the productivity of all areas equally relative to one another.

\section{ENVIRONMENTAL AND LOCATIONAL SITE ANALYSIS}

Despite a fairly robust productive environment at Egiin Gol, it is likely that throughout much of the past, local subsistence involved the three components of agriculture, pastoralism, and hunting-gathering-fishing. Our analysis will focus on intermixes of agricultural and pastoral production, as these were probably the main subsistence activities during the periods of interest. The objective of our analysis will be to assess directly or indirectly (a) the relative extent of agricultural and pastoral emphasis for a given period, (b) the degree of mobility in use, (c) the level of "tethering" to site locations in the sense of site reuse, and (d) the range of productive territory. The archaeological data for our analysis comprise the Egiin Gol settlement and cemetery patterns for the periods of the Xiongnu and Uighur polities. For each period, mean site size and area of habitation in upper or lower 
valley areas will be compared. We expect that periods of higher mobility, lower site tethering, and broader territories will be characterized by smaller habitations on average and lower investment in local mortuary sites in terms of cemetery extent and distribution. Finally, site location should provide evidence for a higher level of pastoral investment as the probable reason behind increased mobility.

In order to assess the degree to which site locations during these two periods are positioned in relation to agricultural or pastoral resource areas, sites will be measured against two landscape data sets consisting of (a) the digitized distribution of Egiin Gol relict agricultural fields and (b) a vegetational index of grassland photosynthetic activity for each tributary valley during the winter-to-summer transition period. A complete set of stereo pair aerial photographs at $1: 25,000$ scale was obtained for the survey area, scanned at $600 \mathrm{dpi}$, and closely examined for evidence of relict fields. Spectrum enhancing software was used to view multiple images of lower and upper valley areas along the Egiin Gol basin, and visible relict fields were outlined on screen. Using an Egiin Gol GIS database with digitized 20-meter contours, tree stands, modern agricultural fields, rivers, and erosion gullies, ground control points were collected for each image having relict fields. The images were projected to latitude-longitude spatial coordinates, and the relict field outlines were redigitized as polygons and then reprojected into a UTM coordinate system. Sites for each period were overlaid on the relict field layer, and buffer rings were extended outward from each site to a distance of $3500 \mathrm{~m}$ (Fig. 5). The area of relict fields included within each buffer ring was measured in order to represent site accessibility to agriculturally productive areas. Such "catchment analysis" has been widely used by archaeologists to assess resource availability from a central habitation site (Roper 1979; Vita-Finzi 1978). The distance of $3500 \mathrm{~m}$ was chosen as an approximate cutoff based on the mean distance between nineteenth-century habitation sites and the geographical centers of the relict field system for each respective side valley having habitation sites (mean $=3448.13 \mathrm{~m})$. Buffers were prevented from expanding across natural barriers, including the Egiin Gol River and areas of high relief, though these cutoffs are not shown on Figure 5. These data were used to compare Egiin Gol sites from the Xiongnu and the Uighur polity periods, the results of which we discuss below.

As mentioned above, based on ethnographic interviews with residents at Egiin Gol, the period of greatest hardship for herd animals is that of late winter through early summer, and therefore those tributary valleys having strong pasture growth in the months between late winter and midsummer will be those of preference for herding (Erdenebaatar 2000). Areas of Egiin Gol having high pastoral productivity were defined according to the mean normalized difference vegetation index (NDVI) as measured for nine $500 \mathrm{~m}^{2}$ blocks per tributary valley and again averaged over the time period December 2000 to July 2001 (13 time measurements for each $500 \mathrm{~m}^{2}$ block). NDVI is a spectral method for measuring vegetational photosynthetic activity using the red and near-infrared reflected energy bands. Reflected red energy decreases with vegetational development and near-infrared reflected energy increases with vegetational growth. By relating the two energy reflectance measurements through the ratio of the red ( $R$ ) and the near-infrared $(\mathrm{NIR})$ as in NDVI $=(\mathrm{NIR}-\mathrm{R}) /(\mathrm{NIR}+\mathrm{R})$, a resulting index value is obtained that is highly sensitive to the amount and condition of vegetation (Huete et al. 


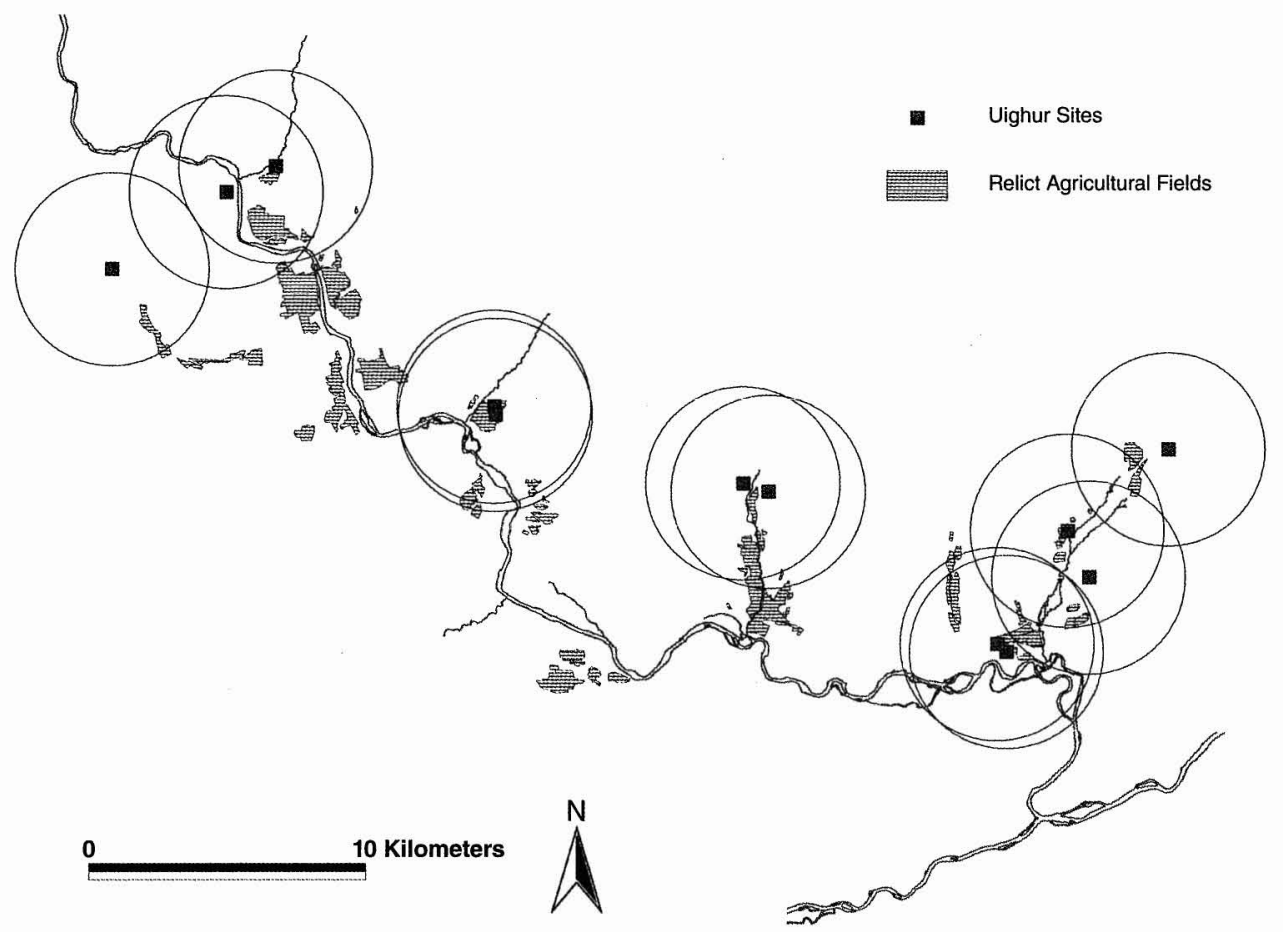

Fig. 5. Buffer measurements $(3500 \mathrm{~m}$ radius) across relict agricultural fields (using Uighur habitations).

1999:4-5). The index ranges from -1 to +1 , where +1 represents maximal photosynthetic activity and 0 represents a nonvegetated soil surface, while subzero values occur for water, snow, stone, and other such inorganic surfaces. We have used MODIS 13A1 [v003] $500 \mathrm{~m}$ NDVI granules to assess the amount of pasture development over the winter-to-summer transition at Egiin Gol. The MODIS data are atmospherically corrected and satellite measurements were taken over a 16-day period in order to minimize cloud interference. Each granule was subsampled with a $500 \mathrm{~m}$ pixel size, reprojected to a UTM coordinate system, and then overlaid with the Egiin Gol digitized map layers. Eight tributary valleys were delimited according to upper, middle, and lower sections, and for each subsection, three $500 \mathrm{~m}^{2}$ blocks were chosen corresponding to a NDVI pixel (Fig. 6). Pixel blocks comprising tree and brush vegetation, watered areas, and agricultural fields were excluded from the measurement to assure that only grasslands were included. Averages over space and time were taken for each tributary valley zone. For each period, the habitation area per $\mathrm{km}^{2}$ in each zone was then compared to the NDVI means in order to examine relationships between areas of maximal settlement and pasture productivity. Archaeological sites for either period that did not fit into any of the eight zones and therefore could not be associated with areas of winter and spring habitation were removed from the analysis ( $\mathrm{n}=2$, Xiongnu). 


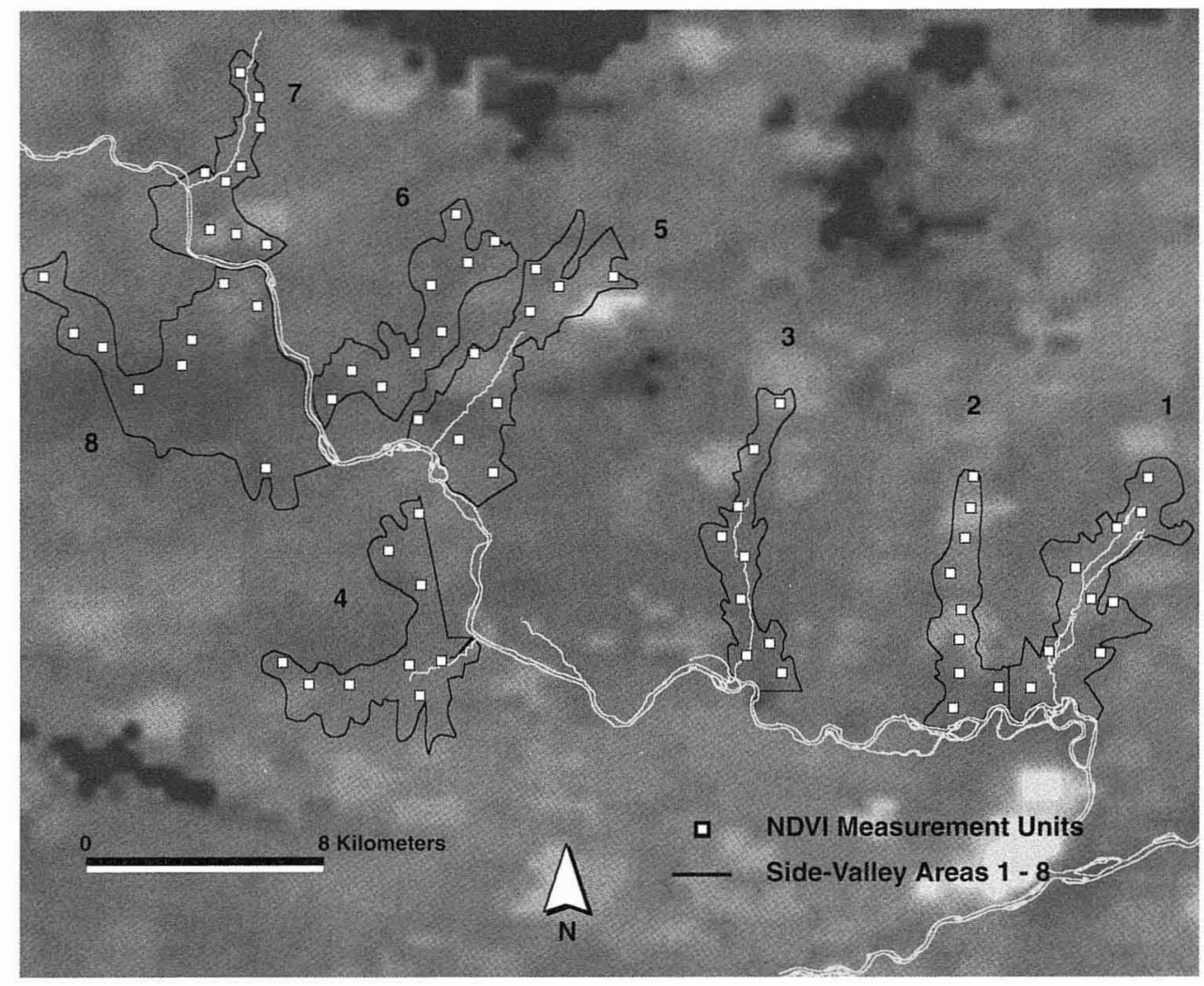

Fig. 6. NDVI $500 \mathrm{~m}^{2}$ measurement units per side valley. The MODIS NDVI granule shown here represents 16 days of vegetation measurements up to March 22, 2001 (areas of lighter shades are more productive).

\section{ANALYSIS RESULTS}

The results of our analyses are reported here along with site information and maps for each period in the Egiin Gol Valley. During the late first millennium B.C., archaeological evidence shows that the Egiin Gol Valley was integrated into the first regional nomadic polity known as the Xiongnu confederation (c. 209 B.C.A.D. 93) (Barfield 1981; Rudenko 1962). Barfield gives a detailed account of the organization of this polity as known from the historical sources, describing it as having at least three tiers of administrative hierarchy organized through a centralized court, a spatially extensive territory, and a high degree of military specialization. Archaeological excavations of Xiongnu cemeteries in Mongolia and southern Siberia have begun to provide evidence for social status differentiation and exchange relationships with a wide range of groups in addition to the Chinese Han dynasty (Loubo-Lesnitchenko 1991; Miniaev 1985; Miniaev and Sakharovskaia 2002). The research of A. V. Davydova (1995) at the Xiongnu settlement of Ivolga near Ulan-Ude, Siberia, provides evidence for intensive agricultural production within the Xiongnu territory and raises the possibility that the economic system of the polity was more complex than might be expected from a 
reading of the Chinese histories. Kh. Perlee's (1961:17-39) survey of several walled settlement sites in central Mongolia, dated to the Xiongnu period, adds further to the growing body of evidence suggesting that the polity was not simply an undifferentiated and homogenous alliance of pastoral nomadic warriors (see discussion in DiCosmo 1994).

Evidence for the integration of the Egiin Gol Valley during the Xiongnu period has been discussed in a separate article, with special attention paid to ceramic diagnostics and the absolute dating of habitation and mortuary sites (Honeychurch and Amartuvshin 2006a). The survey recorded 17 ceramic scatters and six mortuary sites that are characteristically Xiongnu, either by way of sherd diagnostics or based on the distinctive surface construction of Xiongnu burials (Erdenebaatar et al. 1998). ${ }^{7}$ Of the sherd scatters, two sites (EGS 213, 482) were removed from the analysis due to their extremely small size $\left(<40 \mathrm{~m}^{2}\right)$, and three sites (EGS $297,298,299)$ are spatially close enough to be analyzed as a single habitation (distance between the three sites ranges from 90 to $190 \mathrm{~m}$ ). One other site (EGS 120) was also excluded since Xiongnu period ceramics were discovered in and around Bronze Age stone mounds, probably as an example of site reuse. Small-scale excavations amounting to $156 \mathrm{~m}^{2}$ were carried out at four sites of the Xiongnu period. These sites proved to be similar in subsurface composition, consisting of shallow deposits of from 40 to $65 \mathrm{~cm}$ in depth, with ceramic artifacts and faunal remains distributed throughout the soil and lacking stratigraphy. Little evidence for structural investment was found and only two cultural features were uncovered, one a trash pit or ditch and the other a hearth, each at a different site (EGS 486 and 110, respectively). Flotation of the excavated soil from both features yielded carbonized grains identified as bread wheat (Triticum aestivum) and barley (Hordeum sp.) and several instances of unknown domesticated grains (Trigg 2003). Based on this evidence, the sites of this period are interpreted as nonpermanent and probably seasonal settlements.

Of the 11 habitation sites and one special purpose site ${ }^{8}$ included in the Xiongnu period analysis (Fig. 7), nine sites are in the main Egiin Gol Valley, representing a total of 16.11 ha of settlement out of a total of 17.70 ha recorded (91 percent). The remaining site areas are in the middle and upper reaches of the far southeastern valley. Mean Xiongnu habitation size is 1.26 ha. Four of the six Xiongnu burial sites are located in the main valley, and while most of these sites have between one and six burials, the central cemetery (EGS 100), also located in the main valley, is much larger, with over 100 burials (Erdenebaatar et al. 1998). Each Xiongnu habitation was tested for access to productive agricultural lands according to site size (based on relict field distribution) and also tested for proximity to productive grasslands during the winter-to-summer transition (based on tributary NDVI values and period habitation per $\mathrm{km}^{2}$ ). A test for strength of relationship between Xiongnu site size and area of agricultural land encompassed by a $3500 \mathrm{~m}$ buffer, as described above, was performed using Spearman's rank correlation $\left(\mathrm{r}_{\mathrm{s}}\right){ }^{9}$ There is a moderate and significant correlation between the size of Xiongnu sites and the amount of agriculturally productive land accessed within a distance of $3500 \mathrm{~m}\left(\mathrm{r}_{\mathrm{s}}=0.59, \mathrm{p}=0.044\right)$. A similar test was carried out to examine the relationship between Xiongnu period habitation per $\mathrm{km}^{2}$ in each tributary valley and the respective valley's average NDVI measurement for December to July. A weak negative correlation of moderate significance resulted $\left(r_{s}=-0.36\right.$, 


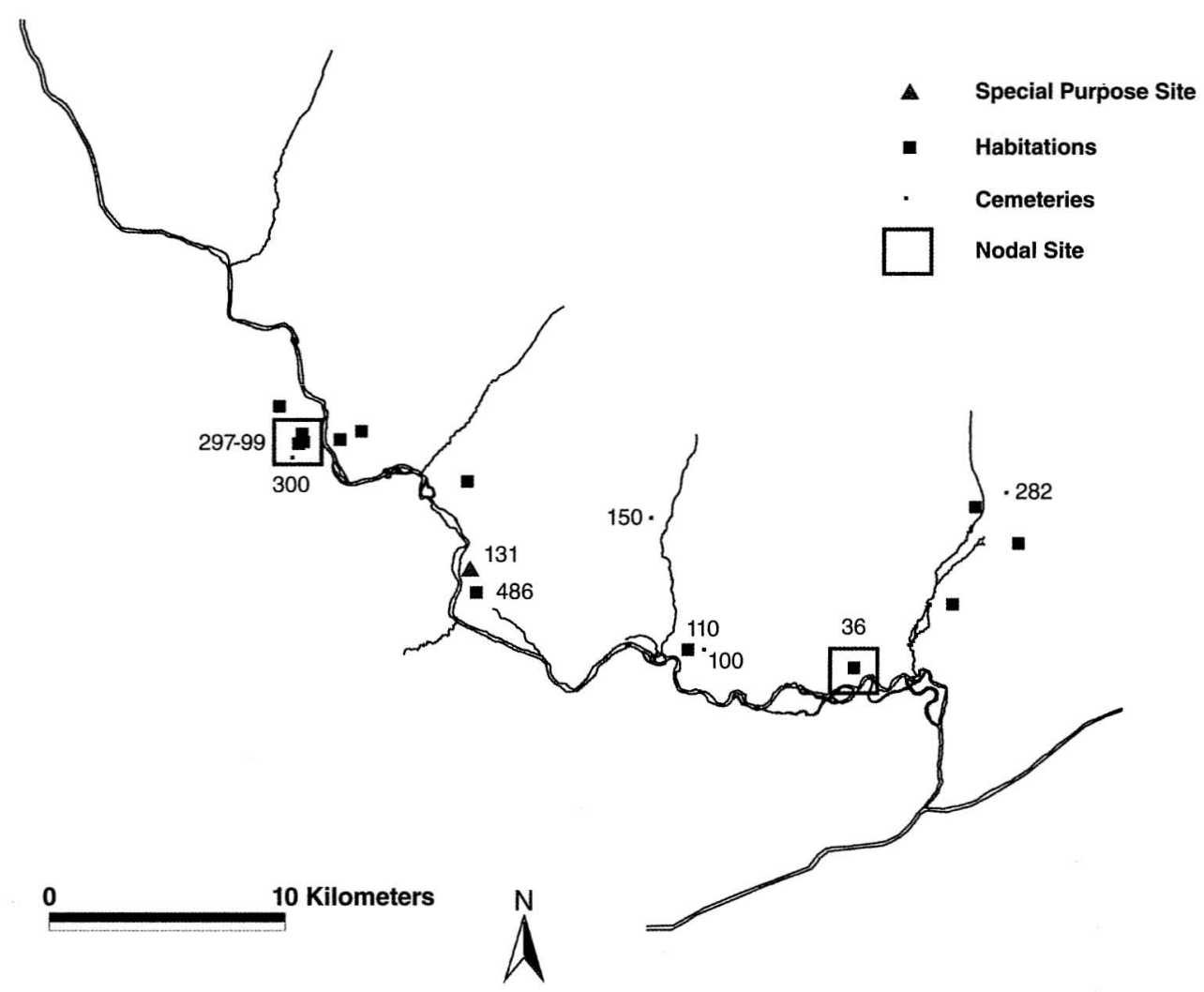

Fig. 7. Xiongnu period site distribution.

$p<0.20$ ), giving little support to the possibility that proximity to areas of higher pasture productivity was a priority during this period..$^{10}$ This is not to say that pastoralism was underutilized at Egiin Gol during the time of the Xiongnu, but rather our evidence suggests that within the local productive mixture of agriculture and pastoralism, agricultural activities may have been increasingly emphasized.

By contrast, the Uighur period in the Egiin Gol Valley (A.D. 744-840) shows a different pattern from that of the Xiongnu period. Like the Xiongnu confederation, the Orkhon Uighurs organized and maintained a complex regional polity that they inherited from their predecessors, the Orkhon Turks (A.D. 553-745). The Uighurs maintained sophisticated long-distance exchange relationships with groups to the west, such as the Sogdian state, as well as with the Tang dynasty of China, and they are known to have created the second writing system developed on the steppe, following that of the Turks. Inscriptions found in the territory of Mongolia and neighboring regions in the Uighur script have been a muchneeded indigenous supplement to the Chinese histories. One interesting development during the reign of the medieval Uighurs was the establishment of walled urban centers in the steppe zone, including the capital city of Khar Balgas ${ }^{11}$ and a secondary center to the north, Baibalik (also transliterated as "Baibalyk"), which is 


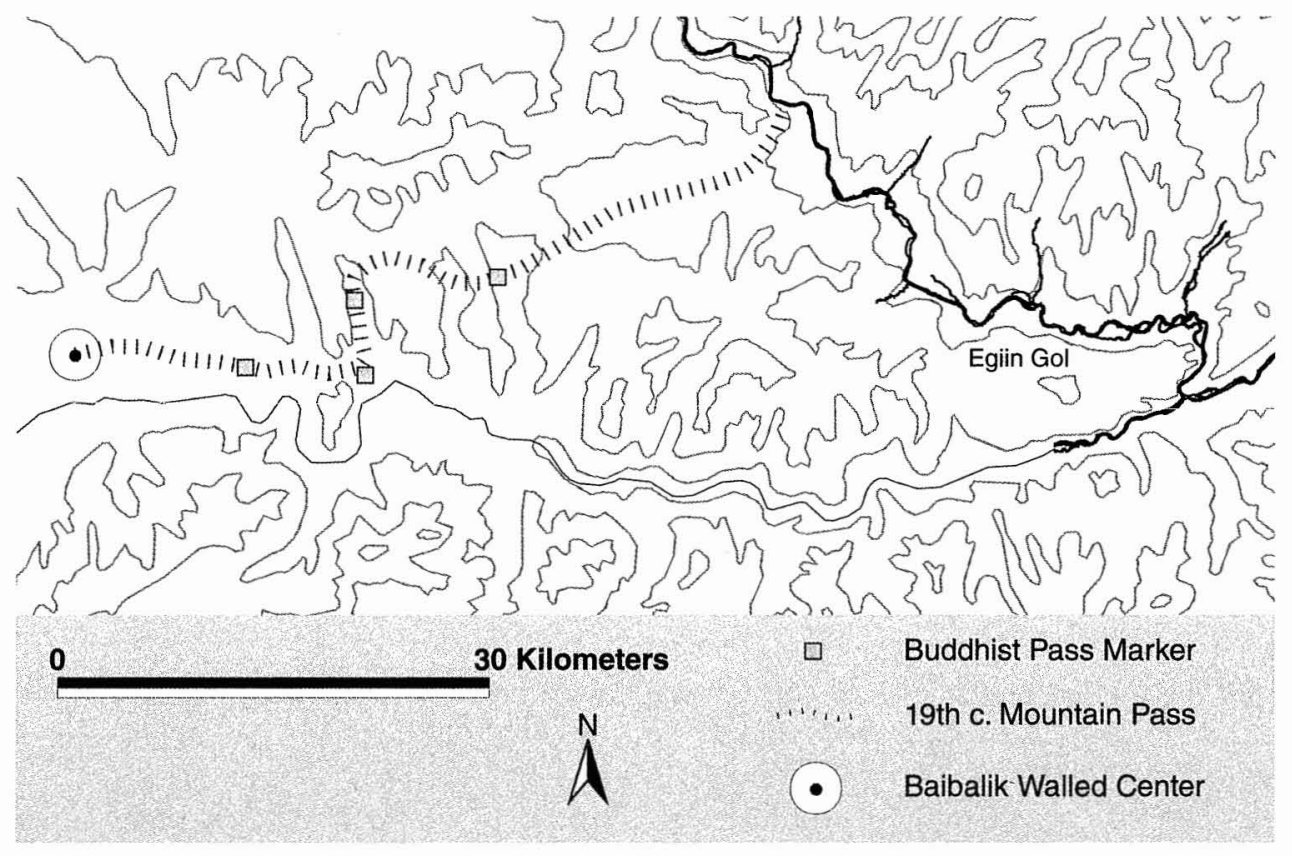

Fig. 8. Spatial relationship between the Uighur center of Baibalik and the Egiin Gol survey area. Nineteenth-century pass system is shown to provide detail on a probable communication route between the urban site and the Egiin Gol hinterland.

located $65 \mathrm{~km}$ southwest of the Egiin Gol survey area (Perlee 1961:49-52, figs. 1 and 8) (Fig. 8). The Egiin Gol site pattern during this time should have some relationship to the founding of this center, a relationship that may help to explain some of the differences detected by our analyses.

Twelve sites at Egiin Gol have been identified as having either Uighur style ceramics, based on type collections made from the Uighur capital site, Khar Balgas, or based on ${ }^{14} \mathrm{C}$ determinations from excavated materials (Hall et al. 1999; Khudiakov and Tseveendorj 1982). In addition, coins have been recovered at two sites in the valley that are known only to occur in archaeological contexts at the site of Khar Balgas and its vicinity, suggesting some relationship between Egiin Gol and these prominent areas to the south (Fig. 9). ${ }^{12}$ Excavation of Uighur sites has produced results similar to the excavations carried out at Xiongnu period sites, with the exception that no evidence for agricultural production was recovered. Otherwise, the total area excavated, the makeup of the archaeological deposits, the lack of cultural features with the exception of hearths, and the recovery of quantities of ceramics and faunal material are all similar to the conditions described for Xiongnu sites. Therefore, the 12 habitations dated to the Uighur period are considered to be nonpermanent seasonal sites. Mean site size is 0.33 ha and total habitation area is 3.95 ha, of which 2.13 ha (54 percent) are located in the main Egiin Gol Valley, while 1.82 ha (46 percent) are located in the middle and upper tributary valleys (Fig. 10).

The nearly equal division of habitation between upper and lower valley areas 


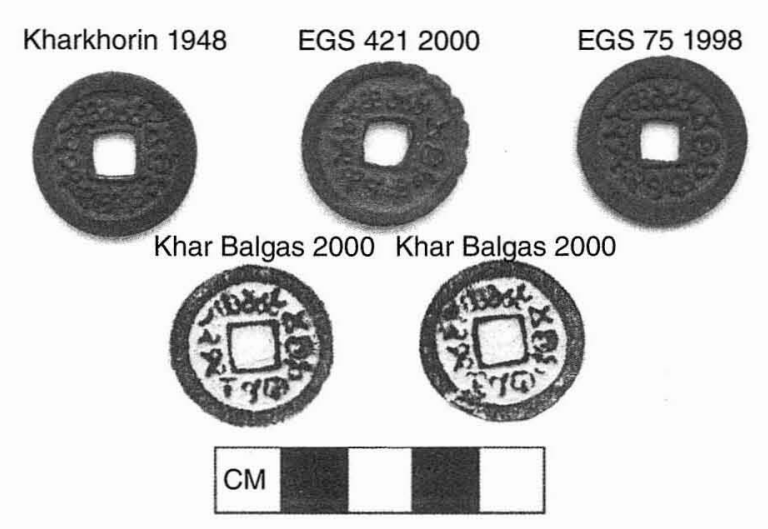

Fig. 9. Coins discovered at Egiin Gol Uighur sites (EGS 421 and 75) and similar coins from the Uighur capital and Orkhon Valley.

closely resembles the present-day ethnographic pattern of landscape use. Three Uighur burial sites have been discovered in the valley, of which one has been excavated, dated, and fully published (Crubézy et al. 1996). The other two burial sites are similar in surface construction, internal arrangement, and faunal assemblages, and all three are single individual burials in prominent landscape locations. The Uighur period at Egiin Gol is not characterized by multiple burial cemeteries as during the Xiongnu period. The results of statistical tests identical to those conducted for Xiongnu sites show a moderately strong and significant correlation between the area of Uighur habitation and the NDVI mean productivity measured for each valley in question $\left(r_{s}=0.68, p<0.05\right)$. Our test of the strength of relationship between site size and access to areas of agricultural production resulted in a very weak positive correlation lacking in significance $\left(\mathrm{r}_{\mathrm{s}}=0.27, \mathrm{p}=0.40\right)$. Based on these environmental tests, Uighur period habitation tended to be located in areas that at present have highly productive pasture during the difficult winter to summer month period. Access to agriculturally productive areas was not correlated with site size in a meaningful way, suggesting a decreased emphasis on agricultural production and an increased emphasis on pastoral production.

\section{DISCUSSION}

The above results are useful in building hypotheses for understanding local and regional modes of integration within nomadic polities and for examining the long-term dynamics that eventually gave rise to the Mongolian Empire of the thirteenth century. Returning to our original categories of analysis, the two environmental tests combined with simple site statistics by period provide a basis for assessing (a) productive emphases, (b) degree of mobility, (c) local "tethering" or site reuse, and (d) extent of accessible territory. For the purpose of developing a comparative sequence, we begin with the site pattern of an earlier period during which time no regional polity was thought to have existed on the Mongolian steppe. The Bronze and Early Iron Age (BEIA) at Egiin Gol is roughly contemporary with the Karasuk and Tagar archaeological cultures of southern Siberia 


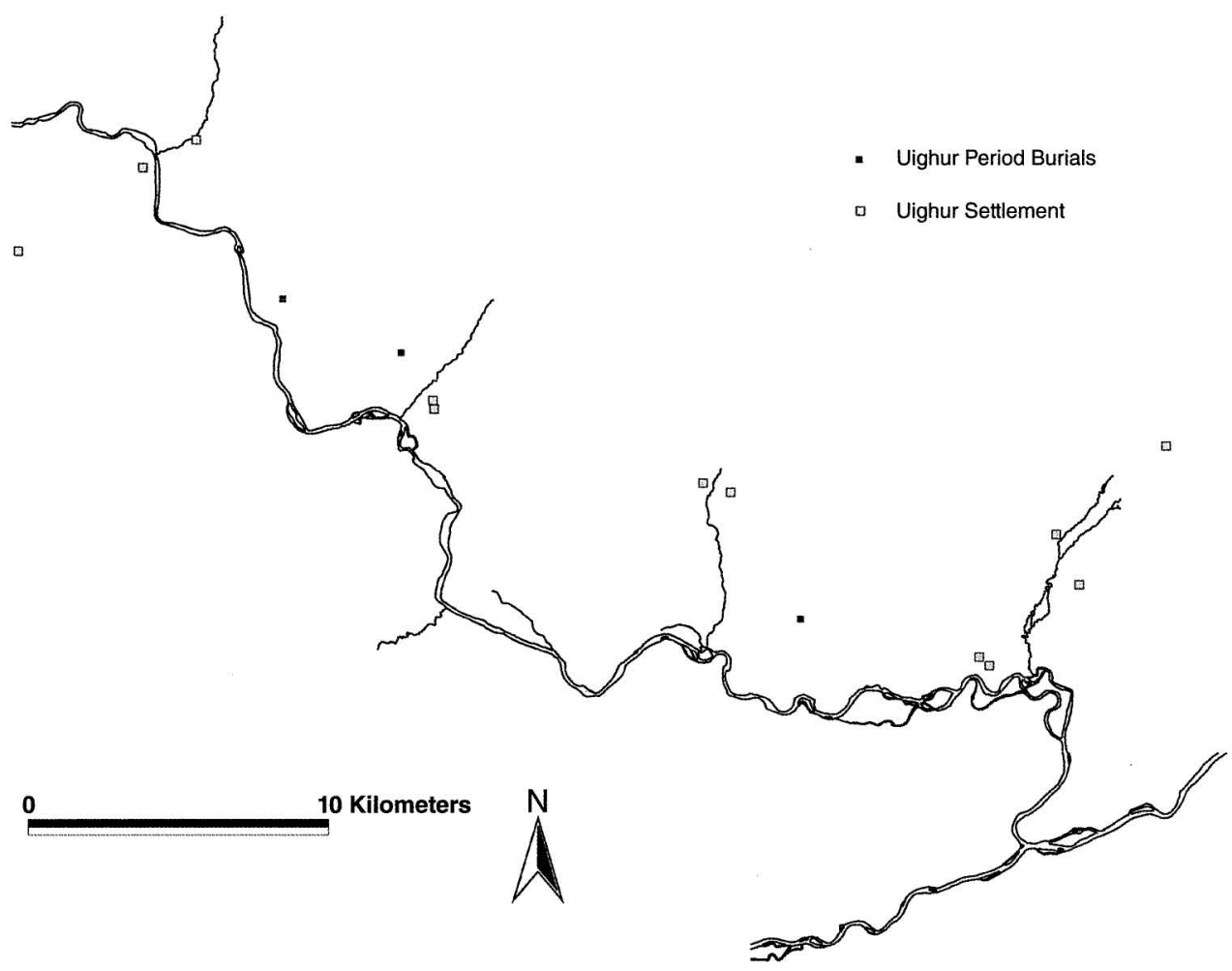

Fig. 10. Uighur site distribution at Egiin Gol.

and dates from the late second to the mid-first millennium B.C. (Askarov et al. 1992). The site inventory is similar to other parts of central and eastern Mongolia during this period and has a distinctly monumental aspect in the form of "animal style" art depictions on stone faces and stelae, large stone mounds with circular or rectangular enclosures (known as khirigsuurs), and mortuary sites made up of small groups of stone slab burials often plainly visible at a distance (Volkov 1967).

A brief examination of all BEIA site types shows a pattern of tributary valley activity, with some tendency for clusters of sites to be located in both the upper and lower valley sections (Figs. 11 and 12). This pattern is similar to the current ethnographic site pattern of upper valley winter use and lower valley summer use; however, the site distributions are relatively confined to the immediate vicinity of the tributary valleys. The BEIA sites drop off in intervening areas along the Egiin Gol basin. This lack of sites could be related to fluvial activity in the valley having resulted in either the destruction or sedimentation of archaeological remains by the Egiin Gol River. However, there exist relatively large, low slope, nonfloodplain grasslands between several of the tributary valleys that altogether lack BEIA sites and suggest that the nonsite areas in the main valley reflect sociocultural and not geological processes. The segmentary distribution of sites and the high densities of monumental features in the form of stone mounds and slab burials suggest to us delimited territories that are demarcated by labor-intensive site construction and very likely nested as segments within a larger territorial and 


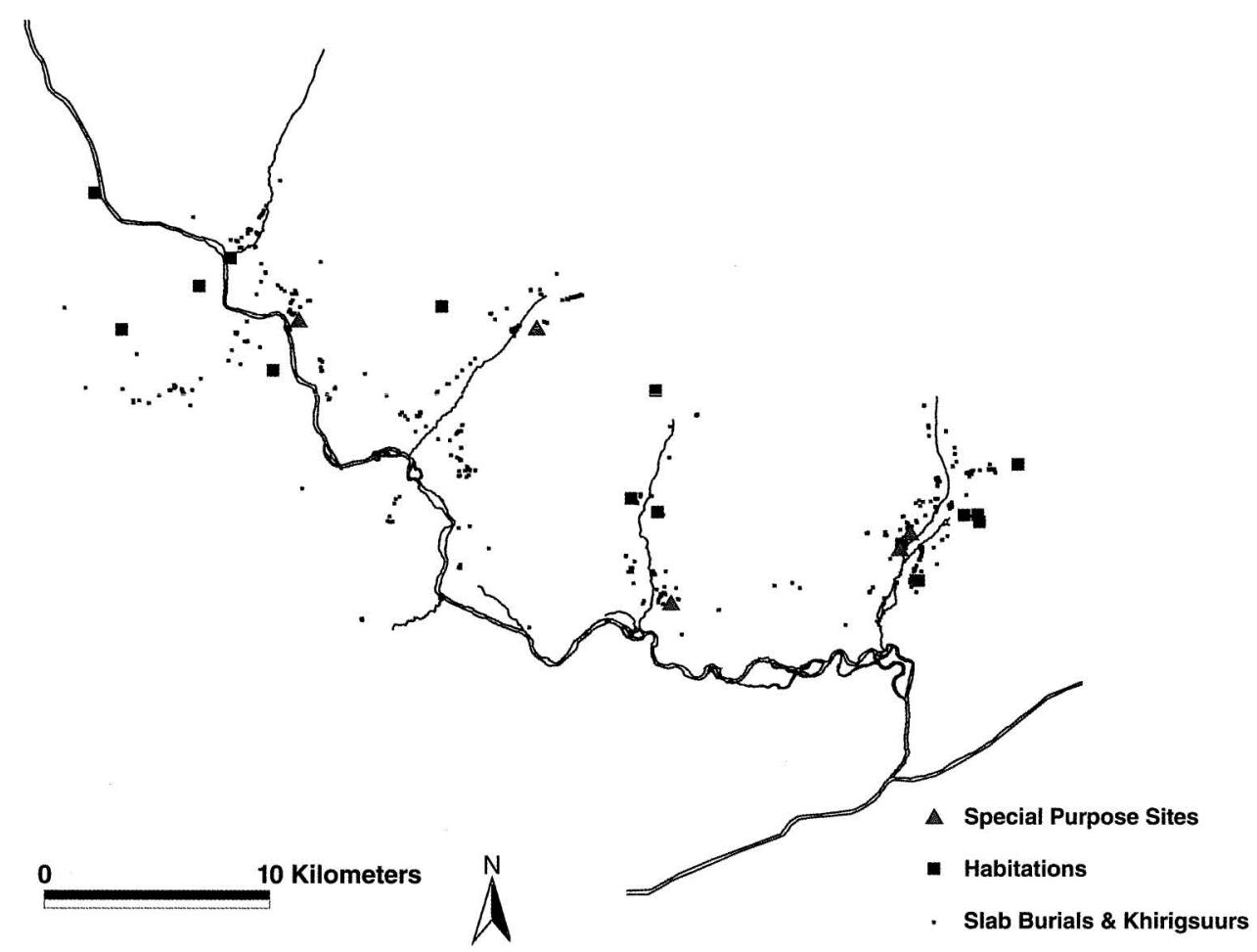

Fig. 11. Bronze and Early Iron Age site distribution at Egiin Gol.

social unit. Habitation sites are very small, with a mean size of 0.25 ha compared to 1.26 and 0.33 ha for the Xiongnu and Uighur sites, respectively. Agro-pastoral production along with relatively high investment in hunting and gathering probably characterized local subsistence. ${ }^{13}$ The range of mobility was not beyond the limits of the lower Egiin Gol River basin since artifact scatters and highly visible monumental sites drop off sharply beyond the main valley and reoccur in other river valleys at distances of 30-40 kilometers from Egiin Gol. Tethering to local tributary valleys was likely to have been of a relatively high degree.

As differentiated from the preceding BEIA, evidence from site locations during the Xiongnu period at Egiin Gol clearly supports a shift in agro-pastoral emphasis toward agricultural production. The identification of significant amounts of domesticated grain from this period enhances our conclusion. Habitation sites were likely seasonal, and their concentration in the main Egiin Gol valley, along with the majority of mortuary sites, implies a summer occupation and perhaps a truncated seasonal pattern. Main-valley summer occupation has been supported by analysis of the faunal assemblages excavated from Xiongnu habitations (Honeychurch $2004: 140$ ). Presumably the majority of winter campsites were located in neighboring riverine valleys, where perhaps pasture and topographical characteristics were superior to the lower Egiin Gol area, which has comparatively shallow tributary valleys. Based on this truncated site pattern, mobility and range of territory seem to have expanded during the Xiongnu period beyond the confines of the survey area and beyond the limits of the BEIA territory. The larger site size 


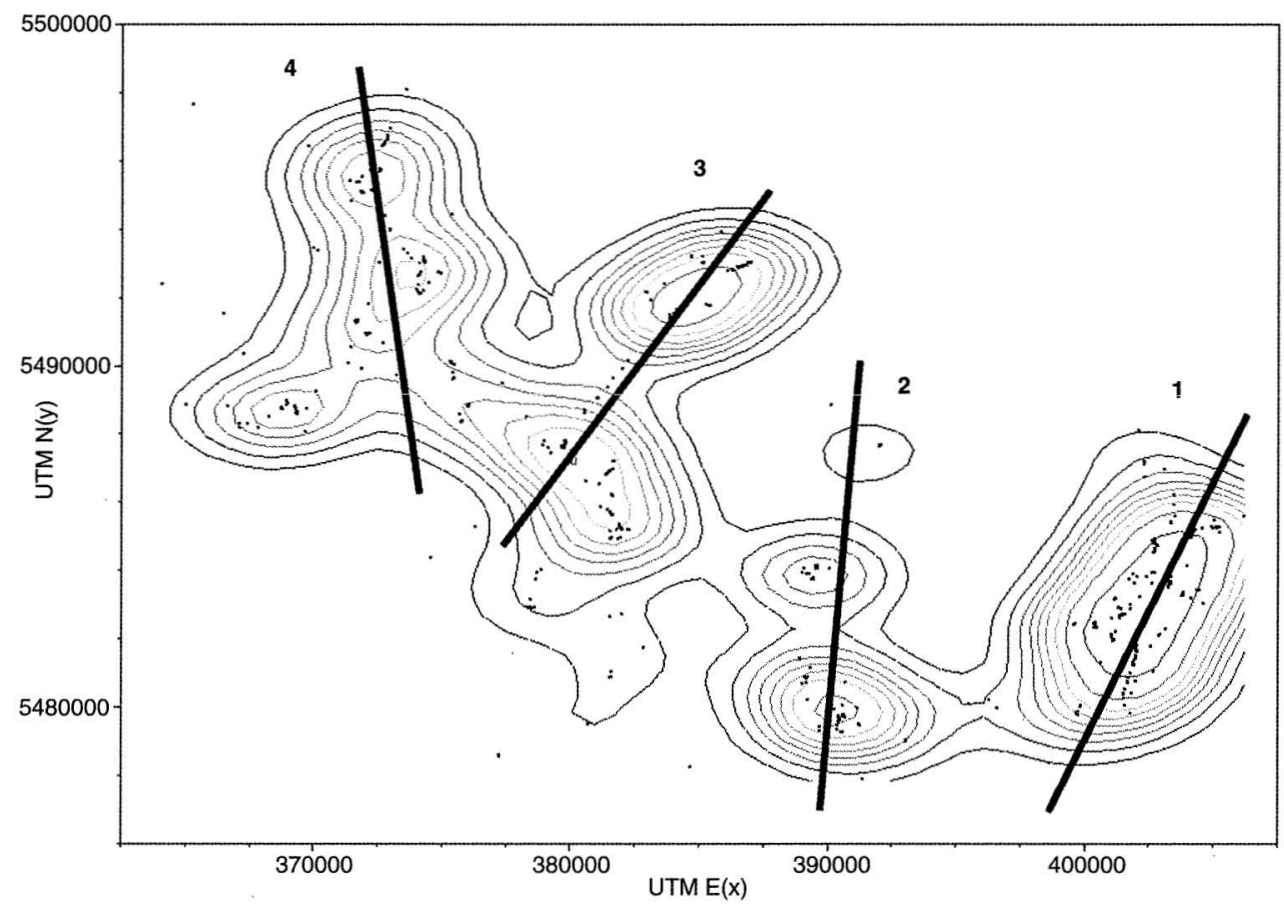

Fig. 12. Bivariate density estimation plot of BEIA sites. Numbers 1-4 and arrows show tributary valleys (contour lines are quantile contours at 10 percent intervals). These tributary valleys correspond to side valleys $1,3,5$ and 7 in Fig. 6.

of these potential summer campsites reflects movement into the valley by higher numbers of individuals from an expanded regional area. Larger site size might also be the result of labor aggregation to support increased levels of agricultural production. Unfortunately, not enough is currently understood about site taphonomy at Egiin Gol, and larger artifact scatters might otherwise have been produced by small family groups returning to a single camp over long periods of time and shifting settlement slightly each season. If this were the case, however, it would suggest that while mobility had increased over an expanded territory, herding groups were displaying an increased degree of tethering to seasonal camp locations. Finally, the Xiongnu period shows a particularly high investment in mortuary activity at Egiin Gol, which may also be associated with seasonal tethering to the lower valley area. The significant depths of Xiongnu tombs, reaching as much as $3 \mathrm{~m}$ below the surface, favor an interpretation of warm season burial construction, since for the better part of the year, Egiin Gol soils are frozen.

These productive and territorial changes associated with the integration of the Egiin Gol Valley into a regionally organized nomadic polity may reflect both economic and political priorities of an increasingly powerful centralized authority. The main problem facing any attempt at centralized integration of valley level groups is the high mobility and military capability of these local peoples, based upon the widespread practices of horse riding and mounted archery (Fletcher 1986:14). The changes implied by the evidence from Egiin Gol might have actually curbed the centrifugal potential of a local nomadic population in the follow- 
ing ways: (1) Expansion of territories and mobility ranges beyond the limits maintained during the BEIA disrupted the authority of local leaders and reduced the cohesion of local groups through changes in group scale; (2) the extraction of tribute from appropriate local areas in the form of agricultural instead of pastoral products placed a valuable resource into the hands of central authorities who could then recirculate grain to areas where agricultural production was impractical for enhanced political influence; and (3) encouraging agricultural production locally would have been a means of "tethering" local groups to predictable locations during the summer and autumn seasons, which are snow-free and therefore the times of maximal mobility across the steppe. In these three hypothetical ways, patterns of change at Egiin Gol may have been related to political strategies of control and integration by an emerging central authority.

Evidence for the Uighur period, which is comparable to the Xiongnu confederation in scale and complexity, shows a different pattern developing at Egiin Gol-one that is potentially related to the advent of urban centers as part of the economic and political management of the regional polity. The extent of time during which the Uighurs were in power on the steppe was less than that of the Xiongnu, but the difference between the two occupations of the valley is qualitative instead of quantitative. From the environmental-locational tests, Uighur habitation seems to be located with an emphasis more on pastoral production than agricultural production. Sites are substantially smaller on average than the Xiongnu period sites, though still somewhat larger on average than those of the BEIA. Uighur site distribution in upper and lower valley locations, based on the ethnographically known patterns, implies occupation during both the winter and summer months. However, Uighur burial patterns in the valley do not provide evidence for substantial investment locally, and this might be due to a reduced level of tethering to the lower Egiin Gol as an area of consistent return. The small site sizes and emphasis on higher levels of pastoral production would also fit well with such an interpretation. Based on our field observations, Uighur artifact scatters are less dense than those of either the BEIA or the Xiongnu period, suggesting a lower degree of site reuse.

Overall, the evidence for the Uighur period points to a decrease in tethering to a single valley, despite the presence there of highly productive agricultural and pastoral resources. This decrease in investment is coincidental with large-scale and urban central place development at the site of Baibalik. Based on historical accounts of the time and archaeological studies, both Khar Balgas and Baibalik were major centers of exchange, specialized craft manufacture, intensive agricultural production, and military garrisoning (Kiselev 1957:95; Lattimore 1962: 255-256). In order to explain Uighur period observations from the Egiin Gol Valley, we suggest that the city of Baibalik, as a political and economic integrating hub, was able to manage a regional network of local groups more effectively than had been accomplished during the Xiongnu period with less direct input to the local area. However, it is not immediately apparent how this might have been achieved given a fixed central place within a fluid and mobile social and productive environment.

One possible explanation to answer this question is that the urban center of Baibalik may not have functioned according to the standard model for urbanism and centrality. Urbanism is in no way alien to the pastoral nomadic steppe, nor 
does it need to be viewed as a process of mimicking external sedentary models for urbanism (Humphrey and Sneath 1999:300). In fact, urban centers were adapted to complement the pastoral productive and social environment, and the process of that adaptation is one in which new relationships and political techniques emerged to become part of an evolving steppe political tradition. An interesting section from the travelogue of Tamim Ibn Bahr, who visited the Uighur court in A.D. 821, states that he found the Uighur khan "encamped in the neighbourhood of his town" (Minorsky 1948:284). In reference to the Kimak group to the north of the Uighurs, Ibn Bahr reports that he "found the king and his army in tents, and in his neighbourhood were villages and cultivated tracts. The king travels from one place to another following the grass." These descriptions of elite mobile courts circulating within environments of both urban "towns" and small-scale villages and agricultural tracts suggest that a different approach to political centralization had been put into place-one that conceives of space in terms of social fluidity and not as a fixed variable.

Historical accounts of such mobile elite courts suggest that a strategic way to monitor a mobile population is for elites themselves to be mobile (Kürsat-Ahlers 1996 : 34). "Urban centers," in this setting, assume the role of impressive points of tether rather than permanent residences. While a large-scale walled site may be an important area for trade, agricultural production, and even defense, the true political "center" circulates along with the elite retinue and therefore should not be conceived of as a point on the landscape but as a polygon of pathways bringing to bear administrative oversight across a broad swath of landscape, both through its presence and the possibility of its presence. Among a nomadic population, such a technique was an important instrument for political control and integration, and it has been a strategy applied by elite in sedentary settings as well (Sinopoli 1994). A combination of effective elite spatial monitoring and seasonal economic benefits tied to the regional center resulted in a decrease in tethering to specific local places such as the Egiin Gol Valley and a scalar increase of more general tethering in orbit of the walled center. Simultaneously, intensive seasonal agricultural production and exchange opportunities presented by Baibalik may have encouraged increased emphasis on pastoral production at the local level as a primary subsistence pursuit and perhaps even as a specialization. Historical sources suggest that pastoral specialization within the regional polity took on additional importance as the intensive production of pastoral commodities, such as horse breeding for exchange to China, developed into a major form of finance supporting the Uighur political infrastructure (Beckwith 1991; Sinor 1972:175; see also Humphrey and Sneath 1999:294).

Using the results of systematic survey from the Egiin Gol Valley and preliminary environmental and locational analysis, we have traced a long-term developmental trajectory describing the relationship of a local area to the emergence of multiple regional polities on the East Asian steppe. Productive changes in intermixed subsistence systems seem closely tied to the scale and structure of regional organization, and therefore the long-standing assumption that the agro-pastoral economy is disarticulated from political change has not been supported by our study. The general pattern of change during the BEIA, Xiongnu, and Uighur periods shows a decline in dependence on the part of local groups upon a particular local area, expansion of territories, and simultaneous improvements in the 
political and economic strategies that bind together and stabilize the nomadic polity. Urban centers were important in the further development of techniques for integrating highly centrifugal, mobile populations; however, such centers had a very different pattern of hinterland integration than might be expected given the common conception of urbanization.

\section{EURASIAN STEPPE LANDS AND THE COMPARATIVE ARCHAEOLOGY OF NOMADIC PASTORALISM}

Recent interest in Eurasian prehistory is reinvigorating an archaeology of nomadic pastoralism (Chang and Koster 1986; Renfrew 2002). The Eurasian steppe traditions of high mobility and dispersed populations, diverse subsistence economies, long-distance networks, and large-scale political entities make for fascinating comparisons when studying issues of pastoral nomadic society, as well as social process more generally. Within the broader domain of steppe archaeology, Mongolia in particular adds a distinctive material record with relevance for research on variation in forms of complexity (Crumley 2001; McIntosh 1999) and imperial organization (Alcock et al. 2001; Sinopoli 2001). With reference to the growing number of archaeological studies on mobile herding societies from the Middle and Near East, the Mediterranean, southern and eastern Africa, and the Andean region, the Egiin Gol survey contributes to discussions on three broad topics: the diachronic nature of pastoral nomadic societies, interrelations between nomadic groups and adjacent civilizations, and sociopolitical complexity among nomads.

The first point demonstrated by the Egiin Gol study is the importance of a long-term perspective on mobile pastoralism that allows us to see shifts in strategy and in productive scale from local networks to those involving expanded territories, larger groups, and urban centers. The long-term view of archaeology reveals processes that are not immediately apparent from either the ethnographic or historical records and that attest to a high degree of socioeconomic sophistication among pastoral nomadic groups (Rosen 2007). A diachronic approach contradicts the more common "static" model for pastoral production, which emphasizes specialization, instability, and underproduction (Cribb 1991:16; Humphrey and Sneath 1999:305). When applied to Mongolian prehistory, such a model underestimates and oversimplifies both the subsistence and political economics taking place on the eastern steppe in conjunction with regional polities (DiCosmo 1994).

The Egiin Gol data instead argue for a more dynamic model of mobile pastoralism. In contrast to the simple "steppe versus sown" dichotomy that has long characterized pastoral studies, steppe subsistence economies are best understood not as a single "type" of production, but as a diachronic process. Mobile agropastoralism as practiced in the Egiin Gol Valley was based upon multiple subsistence resources (agricultural, pastoral, gathering, hunting, and fishing) and the flexibility to readily adjust resource emphasis, mobility, and degree of specialization relative to a shifting environment. Such a lifeway specializes in dynamics and is neither a simple nor rapid cultural transition from other forms of productive organization (Abdi 2003). The flexible, multiresource basis of mobile pastoralism seems to have been a widespread phenomenon across marginal zones where specialized herding is often assumed to have been the default productive strategy. 
Such regions of the ancient world include Inner Mongolia, Kazakhstan, Mesopotamia, and the Levantine Near East, among others (Chang 2003:307; Gilbert 1983: 115; Rosen 2007; Shelach $2005: 31-32$ ).

The key to this kind of lifeway, on the Eurasian steppe and elsewhere, is the relational techniques and traditions of malleable social networks that support shifts in productive inputs and varying degrees of specialization (Cribb 1991:25-27). Within such a framework, rigid distinctions between pastoral and nonpastoral groups are less important than understanding the social repertoire that allows for wide ranges of subsistence variation and recombination at greater and lesser social scales over time. One example arising from long-term ethnographic work among pastoral nomadic groups in the Middle East is the idea that pastoral nomadic societies are built around variation and change by way of institutionalized alternative modes of organization (Salzman 2004:138-139). These modes represent configurations of social relationships and productive emphases that recur as suitable conditions emerge within the local and extralocal environment. The flexibility to transition between a series of modal configurations may account for the relatively rapid appearance and disappearance of specialized herding groups, as witnessed in textual and archaeological records from different parts of the Old World (cf., Rosen 2007; Salzman 2004 : 139-141; Shelach 2005).

Given the flexible and shifting character of many pastoral societies over time, a second point raised by the Egiin Gol case study is the need for reassessing dependency relationships between pastoral nomads and adjacent, state-centered civilizations (Barfield 2001; Khazanov 1994; Kradin 2002). Pastoral nomadism is at times closely interlinked with sedentary agricultural societies-especially those that generate the volume of surplus and exchange associated with mature states. Specialization, however, depends upon secure economic relationships that support an intensive investment in a narrow range of products. When such security does not exist, herding groups opt for more diversified and adjustable production strategies (Salzman 2004:139-141). Where nomadic groups emerged within the interstices of what were predominantly sedentary, agricultural, and urban societies (i.e., enclosed nomadism), nomad and farmer were closely articulated within a broader regional system of economic and political interdependence (Rowton 1977). The eastern steppe zone provides a contrasting example in which sedentary lifeways, large-scale agriculture, and urbanism arose within a primarily mobile herding context (i.e., unenclosed nomadism) to produce an internally differentiated and specialized economy. In other words, the relationships that existed between pastoral nomads and agriculturalists in the past were certainly more complex and variable than the model of nomadic dependency supposes (Chang and Tourtellotte 1998). Those relationships are best studied at multiple social scales, with more attention devoted to context, process, and change and less emphasis on productive typology (Rosen 2007).

Attempts to associate nomadic economic dependency with cultural dependency in order to explain the appropriation of technologies, institutions, and belief systems from sedentary neighbors are also not supported by the eastern steppe record. All societies exist, change, and develop within networks of interrelationships; however, the extent to which nomadic societies are thought to engage in unilateral direct cultural borrowing from adjacent civilizations is, in our opinion, overstated. Such frameworks inhibit a comparative understanding of the role of inter- 
societal contact in both conforming to local cultural contexts and in stimulating indigenous innovation and change (Rogers 1990; Stahl 2002). Our example of the emergence of steppe urban centers is a useful case in point. The concept, form, and technology of urban centers within the eastern steppe setting are often attributed to the direct adoption of urban models from neighboring China by steppe peoples (Rogers et al. 2005). While the need for an impressive central place was expressed through an urban idiom, the nature of the steppe city and its relationship to a mobile hinterland was an entirely novel form of "central place" innovated by steppe nomads specifically for negotiating a mobile sociopolitical and economic context. We propose that much of what is interpreted as direct cultural borrowing on the part of nomads can be profitably understood as processes of innovation and creative "cultural entanglement" rather than dependency (Dietler 1998; Thomas 1991).

Finally, a major question for an archaeology of pastoral nomadism is: in what ways might such an archaeology provide comparisons useful to the study of societies that are neither pastoral nor nomadic? As we have proposed elsewhere (Honeychurch and Amartuvshin 2006b), the Eurasian steppe-and especially the Mongolian record-contributes a unique perspective on sociopolitical organization within a setting that is not typically sedentary, intensive, and agricultural. Such a comparative example opens new avenues for analyzing the role of flexible and adaptive economies within complex organizations (Crumley 1994; Redman and Kinzig 2003) as well as the spatial qualities of political systems over extensive regions (Honeychurch 2004). As one example of the latter case, secondary polities arising in marginal and extensive productive environments tend to emphasize political techniques in support of networking strategies (Blanton et al. 1996:7). The primary character of these techniques is the capability to create, maintain, and utilize economic and political relationships over long distances. Based on the study of Mongolian polities, these capabilities include (1) promoting relationships between far-flung groups that are substantially different from each other in culture, language, and organization; (2) efficiently managing the logistics of overland transport of people, resources, and information; (3) exploiting and controlling logistical networks of movement for political ends; and (4) placing emphasis on organizational characteristics that facilitate interactions over space, such as syncretic and adoptive cultural systems. These qualities are not only valuable for interpreting the steppe tradition of spatially defined politics, but they also represent strategies useful in analyzing other spatially extensive polities, such as the large-scale imperial states of both the Old and New Worlds.

The Eurasian steppe lands hold a distinctive record of lifeways, technologies, interactions, and sociopolitical change that until recently has been inaccessible to Western anthropologists. The Egiin Gol case study is one example of the opening of the Eurasian steppe to research collaborations between anthropological archaeologists and local archaeologists who bring diverse and important points of view into anthropological discourse (e.g., Boyle et al. 2002; Chang et al. 2002; CICARP 2003; Smith and Petersen 2006). While we have mostly addressed issues of mobile herding, it is important to recognize that steppe peoples have placed particular emphasis on aspects of human experience relevant to understanding all societies, including uses and perceptions of space, manipulation of movement and transport, promotion of long-distance interaction, and exploitation of animal resources. The main challenge to an anthropology as seen through the lens of 
steppe adaptations and traditions is to develop that unique perspective in the context of broader questions relating to pastoral and nonpastoral, mobile and sedentary societies alike. Accordingly, we envision the future of Eurasian steppe research as generating new ideas, approaches, and datasets having the potential to reconfigure Old World archaeology and to contribute substantially to the comparative ends of anthropology.

\section{ACKNOWLEDGMENTS}

The Egiin Gol Survey Project received generous support from the Wenner-Gren Foundation. Our work would not have been possible without the assistance of D. Tseveendorj, director, Institute of Archaeology, the Mongolian Academy of Sciences. We would also like to thank the University of Michigan Museum of Anthropology and the Smithsonian Institution, National Museum of Natural History, Department of Anthropology. Particular thanks are due to the people of Egiin Gol, Mongolia, who helped us immensely in understanding their valley. Our work has also benefited greatly from comments, and assistance from Joshua Wright, Mark Hall, Z. Batsaikhan, D. Erdenebaatar, Carla Sinopoli, Henry Wright, Jeffrey Parsons, Daniel Rogers, William Fitzhugh, Bruno Frohlich, Russell Nelson, Greg Indrisano, Robert Drennan, and Rudyard Platt. We thank the three anonymous reviewers whose comments improved our argument and this paper substantially.

\section{NOTES}

1. The personal name has been changed in this case; observations were made in Bayankhongor Khot, Mongolia.

2. We define "Inner Asia" as comprising Mongolia, Inner Mongolia, Tibet, Manchuria, eastern Turkestan (Xinjiang), and parts of eastern Central Asia and southern Siberia (Lattimore 1992 [1940]). We use the term here as synonymous with "eastern Eurasian steppe" or "eastern steppe."

3. The number of herding families mentioned in the text represents the survey area on the northern side of the Egiin Gol River and does not include the village of Khantai located in the northwestern part of the survey area. This small town has about 150-200 inhabitants, some of whom are settled and others who are seasonally mobile. Determining the "pastoral" population in the valley is further hampered by frequent movements of families between the urban center of Erdenet and the Egiin Gol Valley. Based on interviews with the two oldest residents $80+$ years old), population has varied over time within an estimated range of approximately 200 and 500 individuals. Both informants agreed that the current population is lower than that of the early twentieth century. The data represented in Figure 3 are camps observed (summer) and reported (spring, winter, fall) during July 2000 and do not represent a quantitative assessment of family numbers but rather preferences for seasonal campsite location.

4. All detected relict field systems were mapped, and where relict fields clearly appear on both sides of a modern agricultural field at $500 \mathrm{~m}$ distance or less, the modern field was mapped in based on the assumption that it has obscured the earlier fields.

5. While small-scale farming may be carried out in many areas of the main and tributary valleys, larger scale plots are restricted to areas both protected from the flood regime along the main and seasonal rivers and that take advantage of accumulations of productive colluvial soils from hills and small tertiary valleys. The importance of snowmelt and rainfall runoff as water sources also favors these low slope areas along hillsides. Though the modern field patterns are positioned for access by farm machinery at the two ends of the valley, clear overlap of recent fields with nineteenth-century relict fields demonstrates an awareness of these geomorphological variables. According to our project's geomorphologist, "Those places best suited for agricultural production are exactly where we see evidence of agricultural fields today and the geological context has probably not changed dramatically over the past 2000 years" (Bruce Harrison [New Mexico Tech], pers. comm. 1999).

6. Date ranges for each period are those provided by the historical records.

7. Of these six mortuary sites, two are not cemeteries and are represented by only a single burial. The four cemeteries are those located on the map in Figure 7.

8. The so-called special purpose site (EGS 131) is a wall and ditch enclosure with ceramics and other objects dating to the Xiongnu period distributed inside. It is probably not related to habi- 
tation in the same way as other sites and since it is not clearly associated with a side valley, this site is excluded from the NDVI analysis. The relict field analysis includes this site since its status is unclear; however, removing it makes no significant change in the statistical outcome nor does it change the overall interpretation of data.

9. Spearman's rank correlation was chosen over linear regression (Pearson's $r$ ) because some of the values are certainly outlying, and in many cases these are related to important sites having no obvious errors in the measurements associated with them. For this reason, all such values were kept in the analysis, and a test less susceptible to outliers was chosen (see Drennan 1996:233).

10. The NDVI correlation tests are based on tributary valley zones, of which there are eight, and therefore a Spearman's rank correlation lookup table for $\mathrm{n}<10$ was used to calculate the p-values here and for all following NDVI tests (Drennan 1996:233).

11. Khar Balgas is the current name for the archaeological site of the Uighur capital. The original name of the capital city was Ordu Balik.

12. Assistance in identifying these coins or the script that appears on them would be greatly appreciated by the authors. Orkhon Valley collections were made by Kh. Perlee in 1948 (Mongolian Institute of Archaeology collection) and by Z. Batsaikhan in 2000 (Department of Anthropology and Archaeology collection, Mongolian National University).

13. While there is no solid evidence for agricultural production during this period at Egiin Gol, evidence from other sites in the region suggests to some researchers widespread agro-pastoral production. See discussion in Wright 2006:41-45.

\section{REFERENCES}

ABDI, K.

2003 The early development of pastoralism in the central Zagros Mountains. Journal of World Prehistory 17:395-448.

Alcock, S., T. D’Altroy, K. Morrison, and C. Sinopoli, eds.

2001 Empires: Perspectives from Archaeology and History. Cambridge: Cambridge University Press.

Askarov, A., V. Volkov, and N. Ser-Odjav

1992 Pastoral and nomadic tribes at the beginning of the first millennium B.c., in History of Civilization of Central Asia: The Dawn of Civilization to 700 B.C.: 459-468, ed. A. H. Dani and V. M. Masson. Paris: UNESCO.

BARFIELD, $T$.

1981 The Xiongnu Imperial Confederacy: Organization and foreign policy. Journal of Asian Studies $41: 30-36$.

1989 The Perilous Frontier: Nomadic Empires and China. Cambridge: Basil Blackwell.

2001 The shadow empires: Imperial state formation along the Chinese-nomad frontier, in Empires: Perspectives from Archaeology and History: 10-41, ed. S. E. Alcock, T. N. D’Altroy, K. D. Morrison, and C. M. Sinopoli. Cambridge: Cambridge University Press.

BECKWITH, C,

1991 The impact of the horse and silk trade on the economies of T'ang China and the Uighur Empire: On the importance of international commerce in the early Middle Ages. Journal of the Economic and Social History of the Orient 34:183-198.

Blanton, R., G. Feinman, S. Kowalewski, and P. Peregrine

1996 A dual-processual theory for the evolution of Mesoamerican civilization. Current Anthropology 37(1): $1-14$.

Boyle, K., C. Renfrew, AND M. Levine, eds.

2002 Ancient Interactions: East and West in Eurasia. Cambridge: McDonald Institute.

Burnham, P.

1979 Spatial mobility and political centralization in pastoral societies, in Pastoral Production and Society: 349-360, ed. Equipe écologie et anthropologie des sociétés pastorales. Cambridge and New York: Cambridge University Press.

Chang, C., N. Benecke, F. Grigoriev, A. Rosen, and P. Tourtellotte

2003 Iron Age society and chronology in south-east Kazakhstan. Antiquity 77:298-312.

Chang, C., and H. Koster

1986 Beyond bones: Toward an archaeology of pastoralism, in Advances in Archaeological Method and Theory: 97-148, ed. M. Schiffer. New York: Academic Press. 
Chang, C., and P. Tourtellotte

1998 The role of agro-pastoralism in the evolution of steppe culture in the Semirecheye area of southern Kazakhstan during the Saka/Wusun period (600 BCE-400 CE), in The Bronze Age and Early Iron Age Peoples of Eastern Central Asia: 264-279, ed. V. H. Mair. Washington, DC: Institute for the Study of Man.

Chang, C., P. Tourtellotte, K. Baipakov, and F. Grigoriev

2002 The Social Evolution of Eurasian Steppe Communities in Southeastern Kazakhstan: The KazakhAmerican Talgar Project, 1994-2001. Alma-Ata and Sweet Briar College: Nauka.

CICARP (Chifeng International Collaborative Archaeological Research Project)

2003 Regional Archaeology in Eastern Inner Mongolia: A Methodological Exploration. Beijing: Science Press.

Cribb, R.

1991 Nomads in Archaeology. Cambridge: Cambridge University Press.

Crubézy, E., H. Martin, Z. Batsaikhan, and D. Erdenebaatar

1996 Funeral practices and animal sacrifices in Mongolia at the Uighur period. Antiquity $70: 881-889$.

Crumley, C.

1994 The ecology of conquest: Contrasting agropastoral and agricultural societies' adaptation to climatic change, in Historical Ecology: 182-201, ed. C. Crumley. Santa Fe: School of American Research Press.

2001 Communication, holism, and the evolution of sociopolitical complexity, in From Leaders to Rulers: 19-33, ed. J. Haas. New York: Plenum Publishers.

Davydova, A. V.

1995 Ivolginskii arkheologicheskii kompleks: Ivolginskoe gorodishche [The lvolga archaeological complex: lvolga settlement]. Saint Petersburg: Aziatika.

DiCosmo, N.

1994 Ancient Inner Asian nomads: Their economic basis and its significance in Chinese history. Journal of Asian Studies 53(4): 1092-1126.

DieTLER, $M$.

1998 Consumption, agency, and cultural entanglement: Theoretical implications of a Mediterranean colonial encounter, in Studies in Culture Contact: Interaction, Culture Change, and Archaeology: 288-315, ed. J. Cusick. Center for Archaeological Investigations Occasional Paper No. 25. Carbondale: Southern Illinois University.

DRENNAN, R.

1996 Statistics for Archaeologists: A Commonsense Approach. New York: Plenum Press.

ERDENEBAATAR, D.

2000 Bulgan Aimagiin Khutag-Ondor sumyn Khantai bagiin nutag Egiin Golyn khondiid yavuulsan etnografiin ekspeditsiin sudalgaany tailan [Research report of the ethnographic expedition to the Egiin Gol valley of Khantai baga, Khutag-Ondor sum, Bulgan Province]. Field report. Ulaanbaatar: Department of Archaeology and Ethnology, Ulaanbaatar University.

Erdenebaatar, D., U. Erdenebat, T. Torbat, E. Crubezy, P. Maureille, and L. Haye

1998 Burkhan Tolgoin khunnu bulshny sudalgaa [Research on the Xiongnu burials of Burkhan Tolgoi]. Arkheologiin sudlal [Archaeological Research] 18(8): 92-107.

FLETCHER, J.

1986 The Mongols: ecological and social perspectives. Harvard Journal of Asiatic Studies 46:1150 .

Gilbert, A.

1983 On the origins of specialized nomadic pastoralism in western Iran. World Archaeology 15(1): 105-118.

Grishin, I.

1981 Pamiatniki neolita, bronzovogo i rannego zheleznogo vekov lesostepnogo Zabaikal'ia [Monuments of the Neolithic, Bronze and Early Iron Ages of the Forest-Zone of Zabaikal'e]. Moscow: Nauka.

Hall, M., Z. Batsaikhan, and W. Honeychurch

1999 Radiocarbon dates from northern Mongolia. Radiocarbon 41(1): 103-110. 
Halstead, P., and J. O'Shea, eds.

1989 Bad Year Economics: Cultural Responses to Risk and Uncertainty. Cambridge and New York: Cambridge University Press.

HONEYCHURCH, W.

2004 Inner Asian Warriors and Khans: A Regional Spatial Analysis of Nomadic Political Organization and Interaction. Ph.D. diss. University of Michigan, Ann Arbor.

Honeychurch, W., AND C. Amartuvshin

2006a Survey and settlement in northern Mongolia: The structure of intra-regional nomadic organization, in Beyond the Steppe and the Sown: Proceedings of the 2002 University of Chicago Conference on Eurasian Archaeology, ed. D. Peterson, L. Popova, and A. Smith. Leiden: E. J. Brill.

2006b States on horseback: The rise of Inner Asian confederations and empires, in Asian Archaeology: 255-278, ed. M. Stark. Cambridge: Blackwell.

Huete, A., C. Justice, and W. Van Leeuwen

1999 Modis Vegetation Index (MOD13): Alogorithm Theoretical Basis Document. Algorithm Theoretical Basis Document (ATBD), online electronic document. http://modarch.gsfc.nasa .gov/MODIS/ATBD/atbd.html.

Humphrey, C., and D. Sneath

1999 The End of Nomadism? Society, State and the Environment in Inner Asia. Durham, NC: Duke University Press.

IRONS, W.

1979 Political stratification among pastoral nomads, in Pastoral Production and Society: 361-374, ed. Equipe écologie et anthropologie des sociétés pastorales. Cambridge and New York: Cambridge University Press.

JAGCHID, S., AND P. HyER

1979 Mongolia's Culture and Society. Boulder, CO: Westview Press.

JaGChid, S., AND V. J. Symons

1989 Peace, War, and Trade Along the Great Wall. Bloomington: Indiana University Press.

Karabanov, E., A. Prokopenko, D. Williams, and G. Khursevich

2000 A new record of Holocene climate change from the bottom sediments of Lake Baikal. Palaeogeography, Palaeoclimatology, Palaeoecology 156:211-224.

Khazanov, A.

1994 Nomads and the Outside World. Madison: University of Wisconsin Press.

Khudiakov, I., And D. Tseveendorj

1982 Keramika Ordu-balike [Ceramics of Ordu Balik], in Arkheologiia severnoi Azii [Archaeology of Northern Asia]: 85-94, ed. A. Konopatskii and Iu. Khudiakov. Novosibirsk: Nauka.

Kiselev, S.

1957 Drevnie goroda Mongolii [Ancient cities of Mongolia]. Sovetskaia arkheologiia [Soviet Archaeology] 2:91-101.

Kradin, N.

2000 Social evolution among the pastoral nomads, in Alternatives of Social Evolution: 11-15, ed. N. Kradin. Vladivostok: Russian Academy of Sciences (Far Eastern Branch).

2002 Nomadism, evolution, and world-systems: Pastoral societies in theories of historical development. Journal of World-Systems Research 8:368-388.

KürSAT-AhLERS, E.

1996 Aspects of state formation processes among the ancient Eurasian nomads, in The Evolution of Nomadic Herding Civilizations in the Northern European Steppes: The Tools of Archaeology and History Compared. Colloquia of the Thirteenth International Congress of Prehistoric and Protohistoric Sciences 31: 25-48, ed. G. Afanase'ev. Forlì, Italy: ABACO Edizioni.

LABIANCA, O.

1990 Sedentarization and Nomadization: Food System Cycles at Hesban and Vicinity in Transjordan. Berrien Springs, MI: Andrews University Press.

LATTimoRe, O.

1962 Studies in Frontier History. Paris: Mouton Publishing.

1992 [1940] Inner Asian Frontiers of China. New York: Oxford University Press. 
Loubo-Lesnitchenko, E.

1991 External relations of Central Asia according to material from Pazyryk and Noin-ula, in The Chinese and their Northern Neighbors (ca. 1000 BC-ca. 2nd century AD), University of Pittsburgh Symposium Proceedings: ed. K. M. Linduff. Pittsburgh: University of Pittsburgh.

McInTosh, S.

1999 Pathways to complexity: An African perspective, in Beyond Chiefdoms: Pathways to Complexity in Africa: 1-30, ed. S. McIntosh. Cambridge: Cambridge University Press.

Miniaev, S.

1985 K probleme proiskhozhdeniia siunnu [The problem of the origins of the Xiongnu]. Information Bulletin of the Association for the Study of the Cultures of Central Asia 9:70-78.

Miniaev, S., and L. Sakharovskaia

2002 Soprovoditel'nye zakhoroheniia "tsarskogo" kompleksa No. 7 v mogil'nike Tsaram [Accompanying burials of Royal Complex No. 7 at the Tsaram Cemetery]. Arkheologicheskie Vesti [Archaeological News] 9:86-118.

MiNORSKY, V.

1948 Tamim ibn Bahr's journey to the Uyghurs. Bulletin of the School of Oriental and African Studies $12: 275-305$.

Perlee, K.

1961 Mongol Ard Ulsyn ert, dundad ueiin khot suuriny tovchoon [A Brief History of Ancient and Medieval Period Settlements in the Mongolian People's Republic]. Uiaanbaatar: Academy of Sciences.

Redman, C., AND A. Kinzig

2003 Resilience of past landscapes: Resilience theory, society, and the longue durée. Conservation Ecology 7:1, article 14. URL: http://www.consecol.org/vol7/iss1/art14.

RENFREW, C.

2002 Pastoralism and interaction: Some introductory questions, in Ancient Interactions: East and West in Eurasia: 1-12, ed. K. Boyle, C. Renfrew, and M. Levine. Cambridge: McDonald Institute.

ROGERS, J. D.

1990 Objects of Change: The Archaeology and History of Arikara Contact with Europeans. Washington, DC: Smithsonian Institution.

Rogers, J. D., U. Erdenebat, and M. Gallon

2005 Urban centres and the emergence of empires in eastern Inner Asia. Antiquity 79:801-818.

ROPER, D.

1979 The method and theory of site catchment analysis: A review. Advances in Archaeolgical Method and Theory 2:119-140.

Rosen, S.

2007 Desert pastoral nomadism in the longue duree: A case study from the Negev and the southern Levantine Deserts, in The Archaeology of Mobility: Nomads in the Old and in the New World: ed. Hans Barnard. Los Angeles: Costen Institute.

RowTon, M.

1977 Dimorphic structure and the para-social element. Journal of Near Eastern Studies 36:181198.

RUDENKO, S.

1962 Kul'tura khunnov i Noinulinskie kurgany [Khunnu Culture and the Kurgans of Noin Ula]. Moscow: Nauka.

Salzman, P.

1972 Multi-resource nomadism in Iranian Baluchistan, in Perspectives on Nomadism: 60-68, ed. W. Irons and N. Dyson-Hudson. Leiden: E. J. Brill.

2004 Pastoralists: Equality, Hierarchy, and the State. Boulder, CO: Westview Press.

Shelach, G.

2005 Early pastoral societies of northeast China: Local change and interregional interaction during c. 1100 to $600 \mathrm{BC}$, in Mongols, Turks and Others: Eurasian Nomads and the Outside World: 15-58, ed. R. Amitai and M. Biran. Leiden: E. J. Brill. 
Simukov, A.

1934 Mongol'skie kochevki [Mongolian migrations]. Sovremennaia Mongoliia [Contemporary Mongolia] 4(7) : 40-46.

SinOPOLI, C.

1994 Monumentality and mobility in Mughal capitals. Asian Perspectives 33:293-308.

2001 Empires, in Archaeology at the Millennium: A Sourcebook: 439-471, ed. Gary Feinman and T. Douglas Price. New York: Kluwer Academic/Plenum Publishers.

SINOR, D.

1970 Central Eurasia, in Orientalism and History:93-119, ed. D. Sinor. Bloomington: University of Indiana Press.

1972 Horse and pasture in Inner Asian history. Oriens Extremus 19:171-184.

Smith, A., and D. Peterson, eds.

2006 Beyond the Steppe and the Sown: Proceedings of the 2002 University of Chicago Conference on Eurasian Archaeology. Leiden: E. J. Brill.

StAhl, A.

2002 Colonial entanglements and practices of taste: An alternative to logocentric approaches. American Anthropologist 104(3): 827-845.

THOMAs, N.

1991 Entangled Objects: Exchange, Material Culture, and Colonialism in the Pacific. Cambridge, MA: Harvard University Press.

Trigg, $\mathrm{H}$.

2003 Report on Flotation and Wood Samples from Mongolia. Botanical Analysis Report. Boston: Department of Anthropology, University of Massachusetts.

VAinshtein, S.

1980 Nomads of South Siberia: The Pastoral Economies of Tuva. Cambridge: Cambridge University Press.

Vita-FinZi, C.

1978 Archaeological Sites and Their Setting. London: Thames and Hudson.

Volkov, V.

1967 Bronzovyi $i$ rannii zheleznyi vek severnoi Mongolii [The Bronze and Early Iron Age of Northern Mongolia]. Ulaanbaatar: Academy of Sciences.

WRIGHT, J.

2006 The Adoption of Pastoralism in Northeast Asia: Monumental Transformation in the Egiin Gol Valley, Mongolia. Ph.D. diss. Harvard University, Cambridge, MA.

YAMADA, N.

982 The formation of the Hsiung-nu nomadic state. Acta Orientalia 36:575-582.

\section{ABSTRACT}

Archaeological studies of pastoral nomadic societies have been invigorated by recent collaborative research projects across the Eurasian steppe zone. This research contributes an important comparative perspective on processes of complex sociopolitical organization practiced among mobile groups. This essay employs a novel approach to understanding the organizational techniques and methods of finance that supported large-scale imperial polities of eastern Eurasia, specifically those centered on the Mongolian steppe. Using full-coverage survey data from the northern Mongolian valley of Egiin Gol, we present the results of diachronic spatial and environmental analyses in order to evaluate current models for nomadic political economy. We argue that eastern Eurasian subsistence economics are best understood not as a single "type" of production but as a productive process based on multiresource capacities (agro-pastoral, hunting, gathering, fishing) and the flexibility to readily adjust resource emphasis, degree of mobility, and specialization relative to a changeable environment. We offer a revised model for eastern steppe political integration emphasizing the spatial management of political relationships within a mobile setting. Our essay concludes with a brief overview of the potential for Eurasian steppe archaeology to contribute novel comparative insights for anthropologists studying the diversities and commonalities of complex social organization. KEYwords: pastoralism, nomadism, Mongolia, Eurasia, political economy, social complexity, urbanism. 